EXPERIMENTS WITH DROSOPHILA AMPELOPHIIA CONCERNING EVOLUTION

\title{
By
}

Frank Eugene Lutz

QH371 L8 


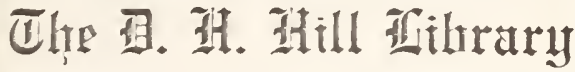

Ainth Caralina state Alniupraity .1371 
THIS BOOK IS DUE ON THE DATE INDICATED BELOW AND IS SUBJECT TO AN OVERDUE FINE AS POSTED AT THE CIRCULATION DESK.

D. H.

N. C. ST 



\section{EXPERIMENTS WITH DROSOPHILA AMPELOPHILA CONCERNING EVOLUTION.}

$\mathrm{BY}$

FRANK E. LUTZ

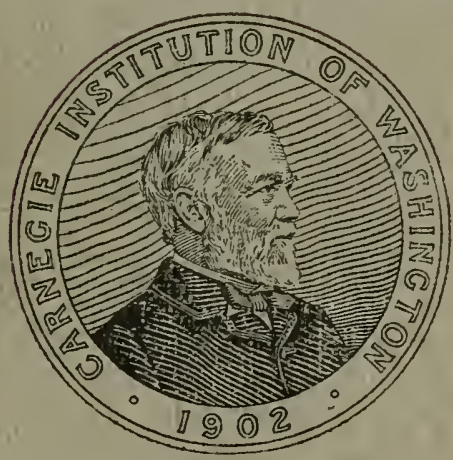

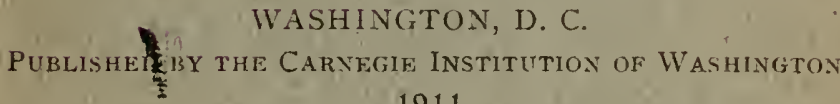
1911 
North Carolina State Library

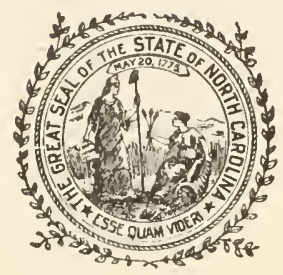

Gift of 


\section{North Carolina State Library}

EXPERIMENTS WITH DROSOPHILA AMPELOPHILA

\section{CONCERNING EVOLUTION.}

BY

FRANK E. LUTZ

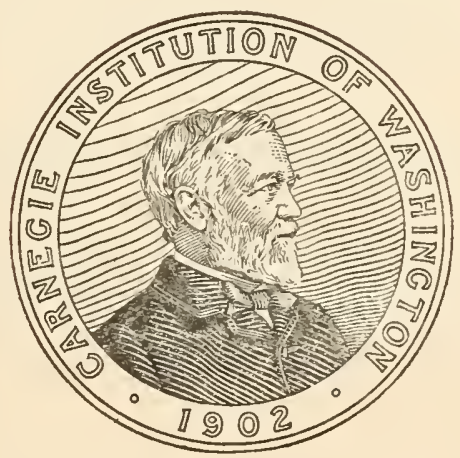

WASHINGTON, D. C.

Published by the Carnegie Institution of Washington 1911 
CARNEGIE INSTITUTION OF WASHINGTON, PUBLICATION No. 143

Paper No. 16 of the Station for Experimental Evolution at Cold Spring Harbor, New York

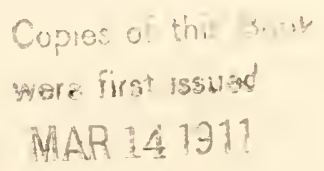

CARLISLE, PA. 


\section{EXPERIMENTS WITH DROSOPHILA AMPELOPHILA.}

THE INHERITANCE OF ABNORMAL VENATION.

THE EFFECT OF SEXUAL SELECTION.

DISUSE AND DEGENERATION. 



\section{THE INHERITANCE OF ABNORMAL VENATION.}

Practically all the experimental studies of inheritance have extended through but few, rarely more than 6 , generations and have been concerned with pairs of non-intergrading characters. In the present work more than 70 generations have been reared. This was possible for two reasons: Drosophila ampelophila Loew has a very short life-history, and it can be kept breeding throughout the year. The character abnormal wing-venation, the inheritance of which was studied, may be made to exhibit extreme variability, passing from less venation than normal through normal to extra venation, so great that the additional veins almost equal the normal in extent.

At the Boston (1907) meeting of the International Zoölogical Congress a preliminary report was presented upon this subject, 6 generations having been obtained. During the summer of 1908 a report upon the work (covering about 25 generations) done at the Station for Experimental Evolution was submitted to the Director, but I deferred publication because I wished to test more in detail certain points, especially sexual selection and the further fate of the abnormal strains. This additional work was done at the American Museum of Natural History. Incidentally I obtained confirmation of the previous work, but for the most part the present paper includes only the Cold Spring Harbor data and the conclusions drawn are as given in the 1908 report, except where otherwise indicated.

MATERIAL AND METHODS.

Drosophila ampelophila (the small red-eyed "pomace-fly") is very common about cider-mills, ripe fruit, vinegar-barrels, and the like. The larvæ normally live in the pulp of rotting fruits, especially during the acetic-acid stage of decay. They will, however, thrive on the side of a tumbler containing fruit-juices, and I have reared them through several generations on stale beer. At a temperature of $25^{\circ} \mathrm{C}$. the eggs hatch in 40 hours or less. The duration of the larval period is, on the average, 5 days, and of the pupal period $4 \frac{2}{3}$ days. The adults become sexually mature about 48 hours after emergence when kept at this temperature. They live for about 3 weeks. The mean number of eggs is close to 200. Copulation is repeated and frequent.

Most of the flies discussed in this paper were bred in an incubator, where an average temperature of $25.5^{\circ} \mathrm{C}$. was maintained. A thermographic record was kept. Since the temperature of the incubator was so nearly that of the working-room, absolute constancy was not obtained. The amount of variation is shown in fig. 1 , which gives the frequencies 
of the different degrees as found during four typical months from readings of the thermogram at 3-hour intervals. For the purpose of these experiments even this approximation to constancy does not seem necessary, as variations of temperature were found to have no influence upon the wing-venation. Therefore the incubator was not used in the latter part of the work.

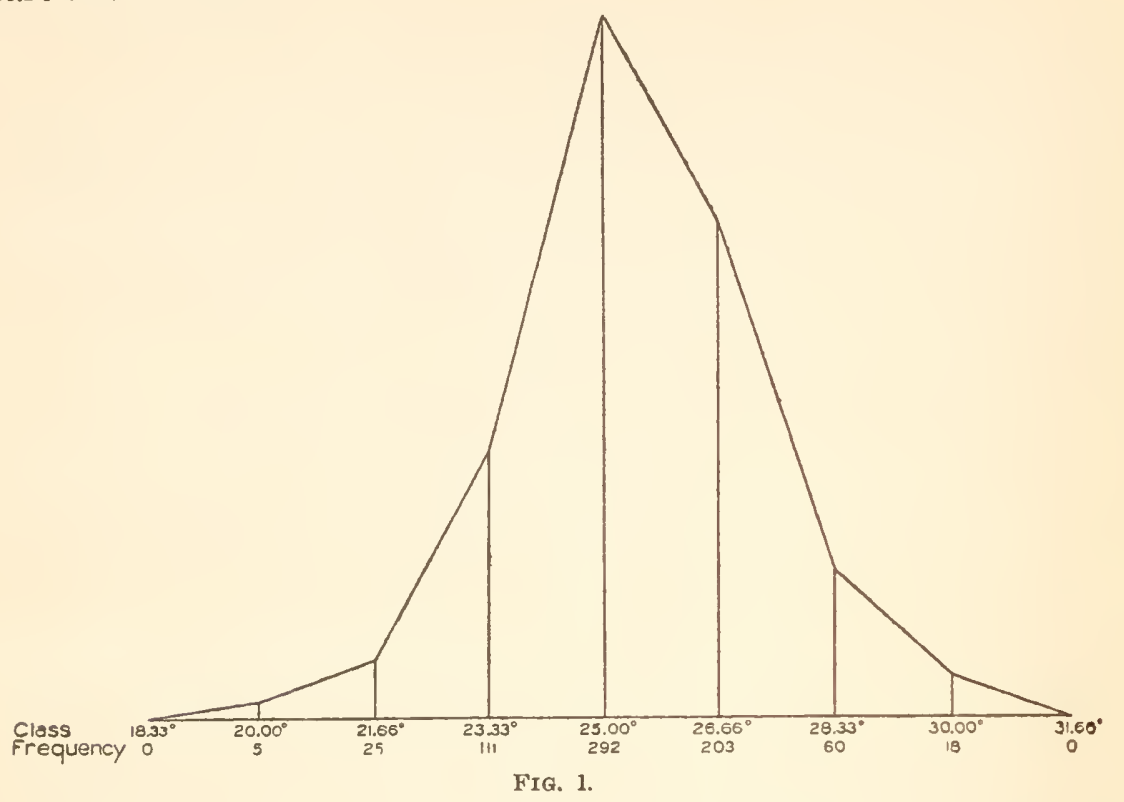

Bananas were used as food. They were purchased while still quite green and ripened in glass-stoppered bottles. In this way accidental introduction of wild flies was rendered unlikely. Even had Drosophila eggs been laid on the green banana, they would have hatched and the larvæ would have developed into plainly visible pupæ before the banana was used. Frequent control-cultures were kept and in no case was a Drosophila found in them. The flies with their food were kept in carefully washed glassware and the instruments used in handling the food were sterilized in an alcohol flame after every operation which could possibly get eggs or larvæ upon them. The importance of this caution can not be too strongly urged upon those who carry out pedigree-work with this insect.

An egg-laying female was given a fresh piece of banana every two days and an effort was made to have all the banana of the same degree of decay. Each piece was kept separate during the growth of the larvæ. This also is important, since, if one merely gives a large supply of food to the female at the start of oviposition, and does not change it, the early-born larvæ will have very different food from those which are born later. The pupæ were picked out of the "larval dish" and placed 
upon moist blotting-paper in a small vial, from which the adults could readily be transferred to an etherizing vial as they emerged.

When mating was to be done the sexes were always separated before they were a day old. Usually no female was used as a parent that was more than 12 hours old before being isolated from the males. Numerous tests showed that no females so treated laid fertile eggs. Only rarely was there a difference of more than one day in the ages of the parents, and they were usually mated before they were two days old. For practical reasons, parents were killed after 50 to 100 offspring had been secured. It was found that neither the percentage of abnormal offspring nor the intensity of their abnormalities changed with the age of their parents, so that this procedure was permissible.

In this paper only those families are considered which are in or close to the main line of descent. I have not thought it worth while to include any families having less than 40 offspring unless they were in this main line. Typical data are given in table 36 , page 31 . I have tried to arrange these so that they will be available for further work by those interested. They should not, however, be used for more than they are worth. For example, one can not study the inheritance of fecundity from them, as in but few cases have I bred from a female until she died a natural death.

All individuals, both parents and offspring, have been kept for reference and are deposited in the American Museum of Natural History. When of especial interest, the wings were mounted on glass slides in a thin layer of paraffin. This was found to be an excellent method of preservation. By all other methods which were tried the veins were rendered more or less transparent. When, as in making matings, it was desired to examine live flies, they were slightly etherized. They completely revive in a few minutes. All examinations for abnormalities in wing-venation must be made with a lens.

Occasionally the larvæ were attacked by a disease (?) of unknown origin which caused them to crawl out of the food, elongate, and die. When this disorder appeared in a dish it was usually fatal to all the larvæ in that dish. Otherwise, Drosophila bears confinement very well. Practically all the larvæ which hatch complete their development. My experience confirms the results reached by Castle (1906b) that the closest inbreeding may be practiced with this fly for generations with no injurious results. Such inbreeding was the rule in this work, being necessary in long-continued breeding unless unpedigreed stock be used.

\section{DESCRIPTION OF NORMAL VENATION.}

The normal venation of Drosophila is extremely simple, as is shown by fig. 2 . The costal vein reaches to the fourth of the five longitudinal veins. The auxiliary vein is incomplete or indistinct. The anal cell is present. The discal and second basal cells are united and the first posterior cell is not appreciably narrowed in the margin. 


\section{DESCRIPTION OF ABNORMAL VENATION.}

It is probable that all insects occasionally show some abnormality of wing-venation. In my experience with Drosophila ampelophila they occur in one-third of 1 per cent of wild specimens. The data concerning this point are given in table 1 . In these the abnormalities consisted of irregularities of the second longitudinal vein or small dashes near its distal end (similar to figs. 3 to 10). Only one of the 19 abnormal* wild $^{*}$ flies I have seen was abnormal in both wings.

TABLE 1.-Percentage of wild Drosophila ampelophila which have extra veins in their wings.

\begin{tabular}{|c|c|c|c|}
\hline & Normal. & $\begin{array}{c}\text { Abnor- } \\
\text { nal. }\end{array}$ & $\begin{array}{l}\text { Percent- } \\
\text { age of } \\
\text { abnormal. }\end{array}$ \\
\hline $\begin{array}{l}\text { Bloomsburg, Pa....... } \\
\text { Huntington, N. Y. ... } \\
\text { Woods Hole, Mass.... } \\
\text { Boston, Mass........... }\end{array}$ & $\begin{array}{r}1165 \\
697 \\
2083 \\
1660\end{array}$ & $\begin{array}{l}8 \\
3 \\
3 \\
5\end{array}$ & $\begin{array}{l}0.68 \\
0.43 \\
0.14 \\
0.30\end{array}$ \\
\hline Total...... & 5605 & 19 & 0.34 \\
\hline
\end{tabular}

While rearing this insect for another purpose, several such abnormal specimens were found in one family. My principal abnormal strain, in which the variety and amount of abnormality is little short of astounding, came from these. The various figures give a better conception of what was obtained than would verbal description. There is the utmost variation in the abnormal venation, not only in different flies, but in the different wings of the same fiy. The majority of the abnormalities are in the distal portion of the marginal cell, but they have been found also in the submarginal and a few in the first, second, and third posterior cells, affecting all the longitudinal veins except the first.

\section{CORRELATION BETWEEN THE RIGHT AND THE LEFT WINGS.}

One wing may be abnormal, or both may be. In the latter case the abnormality may be great in one wing, small in the other; on one vein in one wing and lacking on this vein but present on others in the other wing (see figs. 44 to 46). Nevertheless there is a correlation between the intensity of the abnormality in the two wings, as is made clear by tables 2 and 3 . In drawing up these tables the range of variation of the intensity of the abnormality was divided arbitrarily, since the character is not quantitatively measurable, into six classes: normal venation (or zero intensity of the abnormality), very slight (see figs. 3 to 7), slight (see figs. 8 to 11), medium (see figs. 12 to 18), great (see figs. 19 to 24 ), and very great (see figs. 25 to 35 ). To which class a given wing should be assigned is a matter of judgment; but since when these tables were made up it was thought that there was no correlation be-

\footnotetext{
"Unless otherwise stated "abnormal venation" means, throughout this paper,
} 
tween the two wings with respect to the intensity of abnormality, the personal equation which entered in would have tended to make the correlation as shown by the tables too low rather than too high. The arabic

TABLE 2.-Correlation between right and left wings of males.

[For explauation sec page 4.]

\begin{tabular}{|c|r|rr|r|rr|r|}
\hline N. & N. & V. S. & S. & M. & G. & V. G. & \\
\hline & 413 & 48 & 33 & 34 & 3 & & 531 \\
V. S. & 340 & 79 & 46 & 58 & 17 & \\
& 48 & 23 & 8 & 14 & 1 & 94 \\
S. & 60 & 12 & 8 & 10 & 3 & \\
& 23 & 15 & 9 & 15 & 9 & 71 \\
M. & 46 & 9 & 6 & 8 & 2 & \\
G. & 20 & 14 & 17 & 14 & 9 & 74 \\
& 47 & 10 & 7 & 8 & 2 & \\
V. G. & 3 & 3 & 2 & 9 & 2 & 1 & 20 \\
& 13 & 3 & 2 & 2 & 1 & & \\
\hline & 1 & & & & 1 & & 1 \\
\hline
\end{tabular}

TABLE 3.-Correlation between right and left wings of females.

[For explanation see page 4.]

RIGHT.

\begin{tabular}{|c|c|c|c|c|c|c|c|}
\hline & N. & V.S. & S. & M. & G. & V. G. & \\
\hline N. & $\begin{array}{l}226 \\
150\end{array}$ & $\begin{array}{l}43 \\
51\end{array}$ & $\begin{array}{l}37 \\
57\end{array}$ & $\begin{array}{l}47 \\
73\end{array}$ & $\begin{array}{r}1 \\
18\end{array}$ & 5 & 354 \\
\hline V. S. & $\begin{array}{l}42 \\
46\end{array}$ & $\begin{array}{l}22 \\
16\end{array}$ & 21 & $\begin{array}{l}20 \\
23\end{array}$ & $\begin{array}{l}3 \\
6\end{array}$ & $\begin{array}{l}1 \\
2\end{array}$ & 109 \\
\hline S. & 25 & 20 & 33 & 37 & 12 & 1 & 128 \\
\hline M. & $\begin{array}{l}42 \\
67\end{array}$ & $\begin{array}{l}25 \\
23\end{array}$ & $\begin{array}{l}33 \\
25\end{array}$ & $\begin{array}{l}46 \\
33\end{array}$ & $\begin{array}{r}10 \\
8\end{array}$ & $\begin{array}{l}2 \\
2\end{array}$ & 158 \\
\hline G. & 9 & 7 & 6 & 13 & 11 & 4 & 50 \\
\hline \multirow[t]{2}{*}{ V. G. } & & & & 5 & 6 & 4 & 15 \\
\hline & 344 & 117 & 130 & 168 & 43 & 12 & 814 \\
\hline
\end{tabular}

numbers show the observed conditions ; the italics show the distribution of frequencies which would have been expected had there been no correlation. The fact that expectation is exceeded by observation in those classes where the intensity is alike, or nearly so, in each wing, but is not 

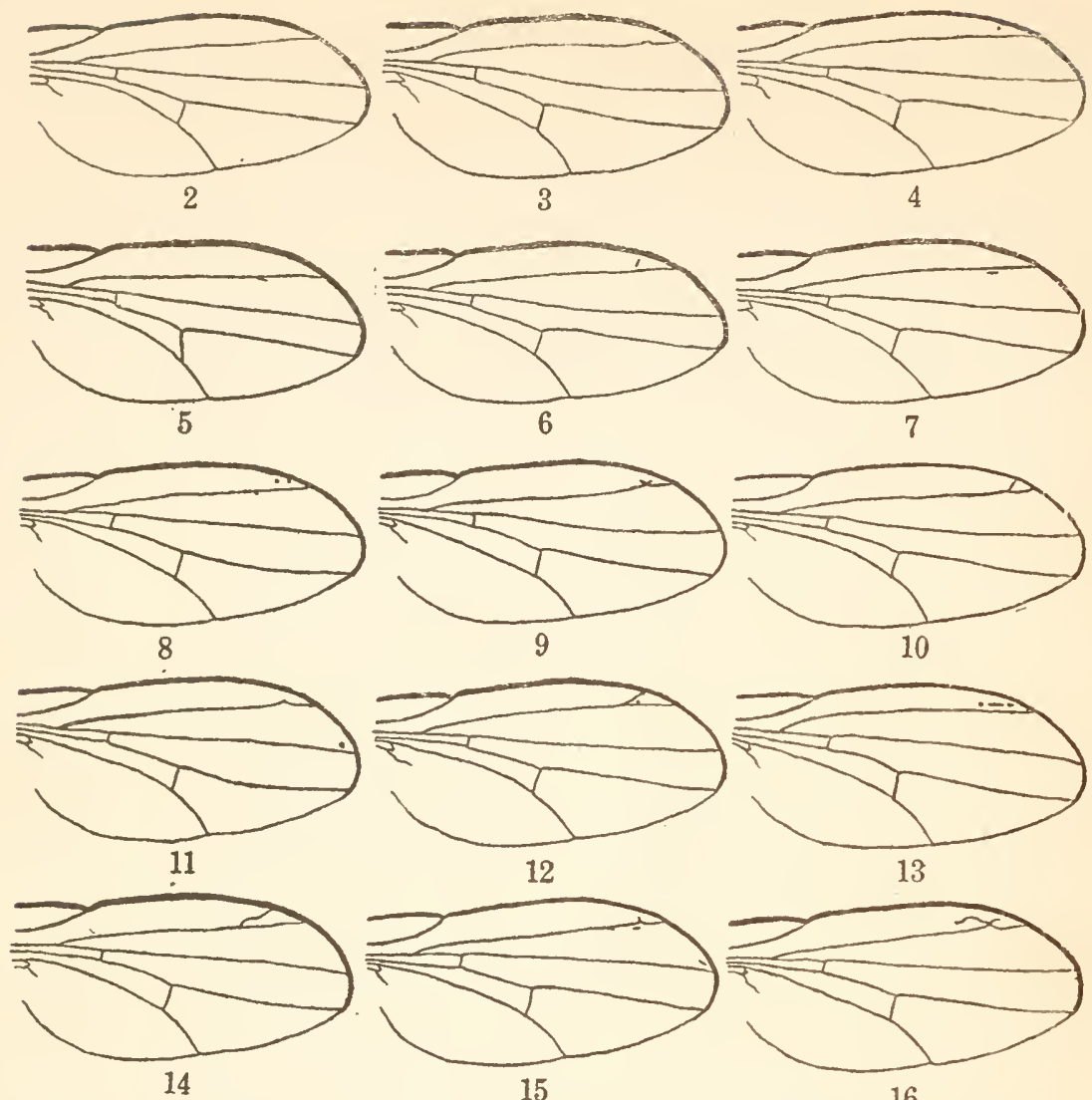

15
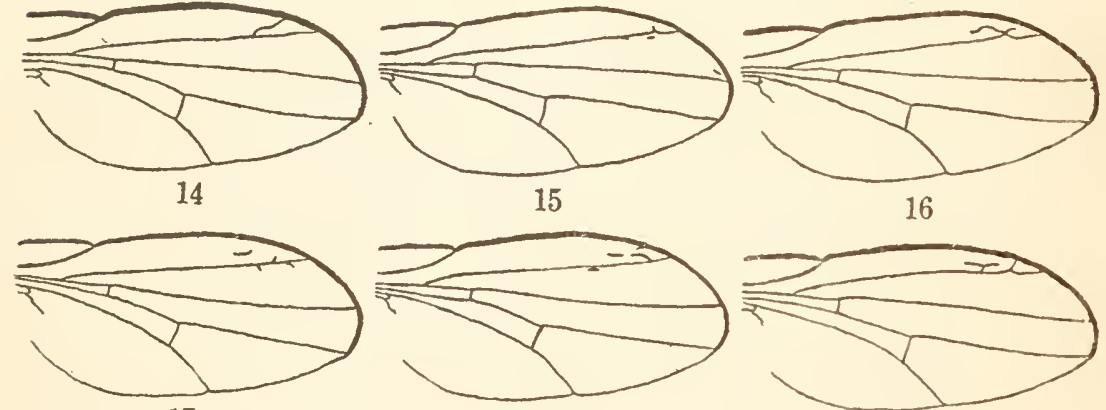

17

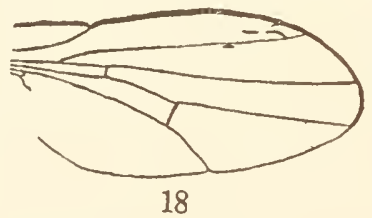

16

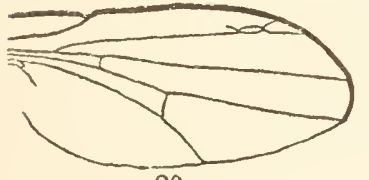

20

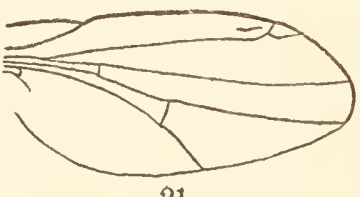

21

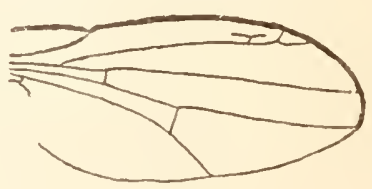

19

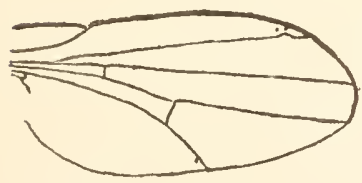

23

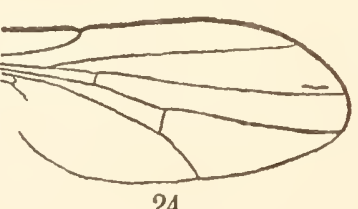

24

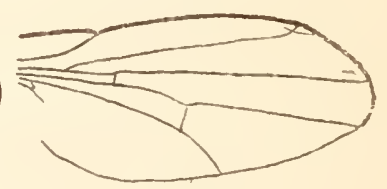

22

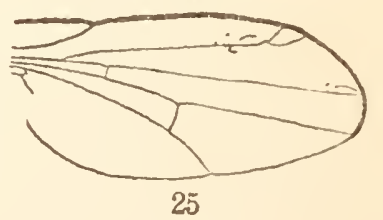



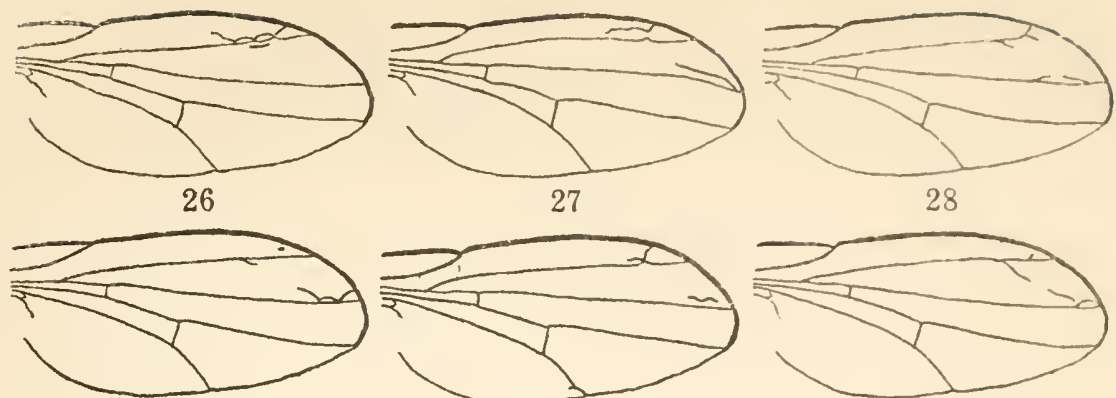

27

28

29

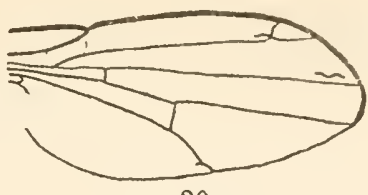

30
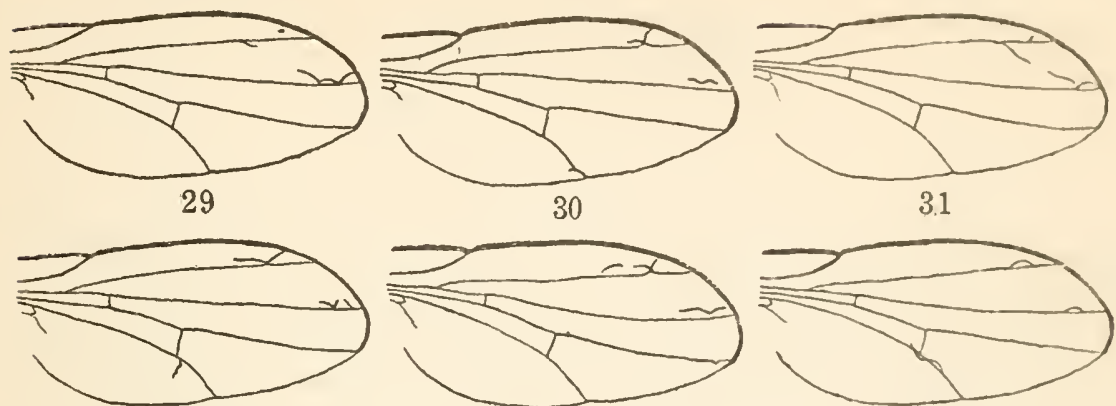

32

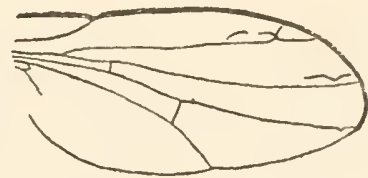

33
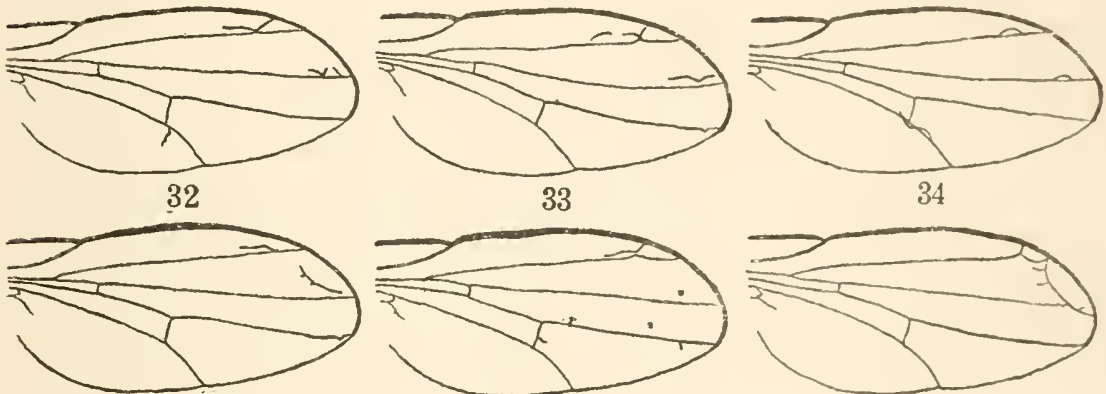

35

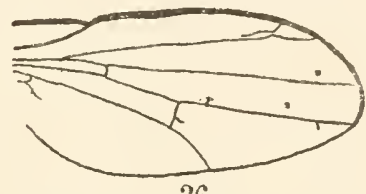

36
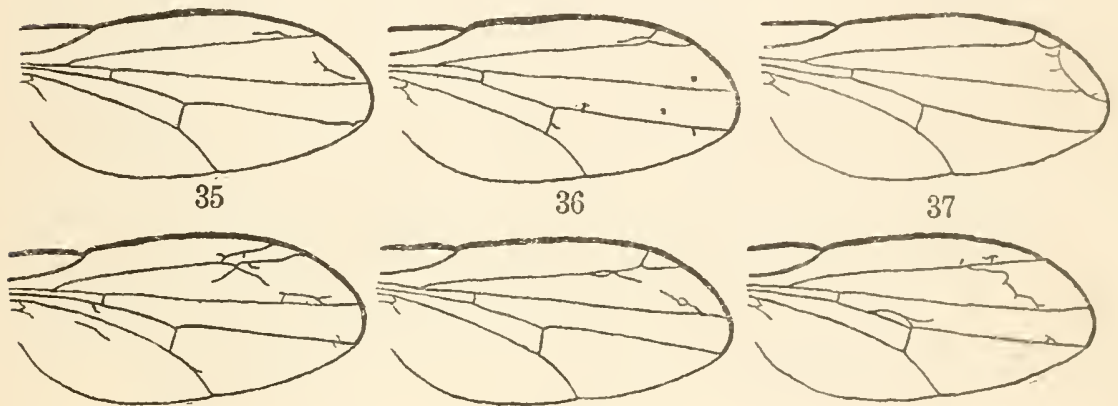

38

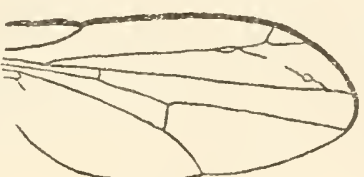

39
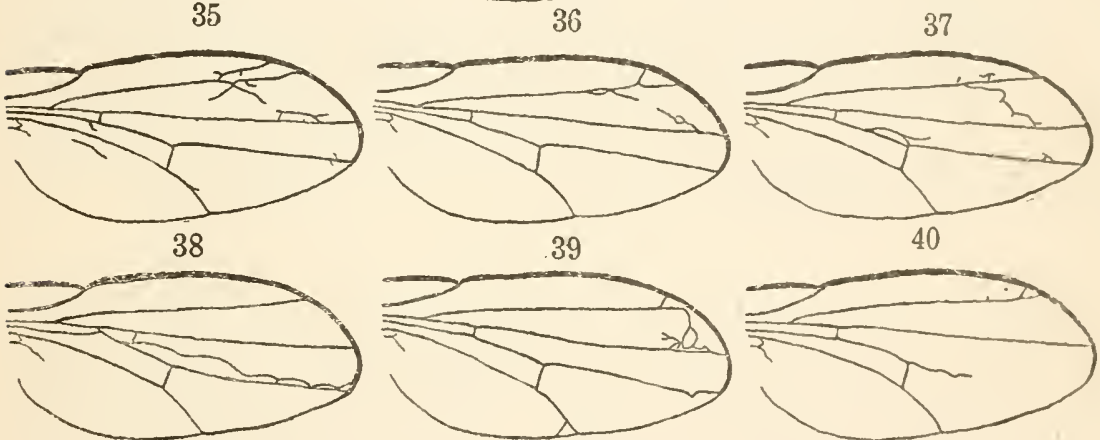

41

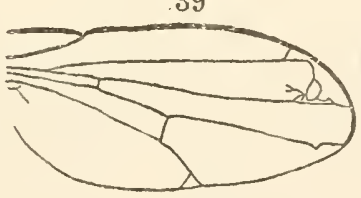

42

40

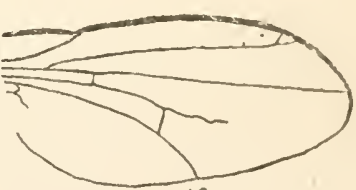

43

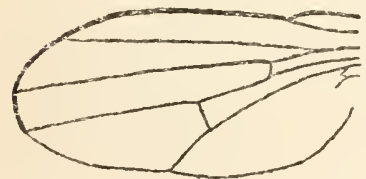

$44 a$

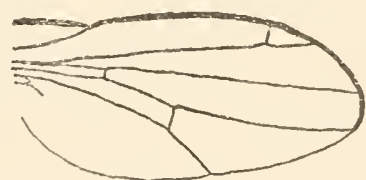

$44 \mathrm{~b}$
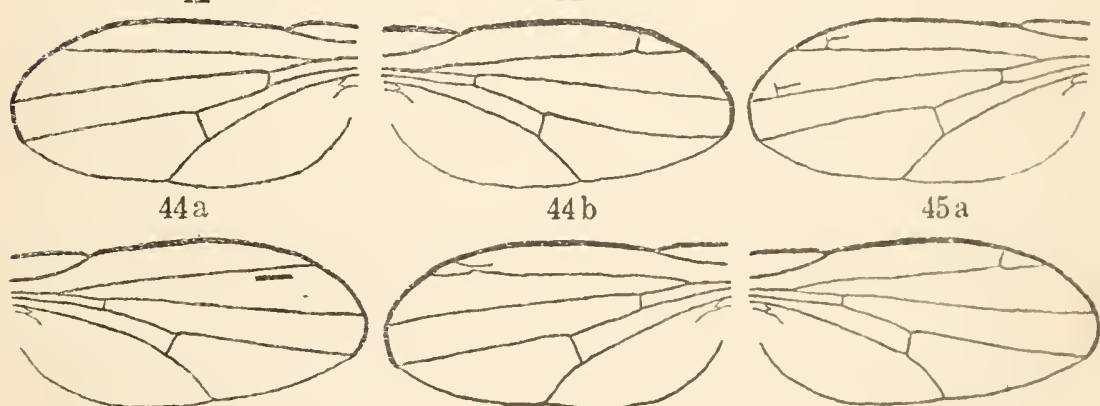

$45 \mathrm{~b}$

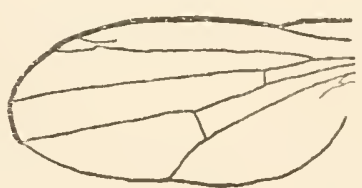

$46 \mathrm{a}$
45 a

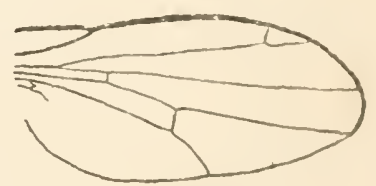

$46 \mathrm{~b}$ 


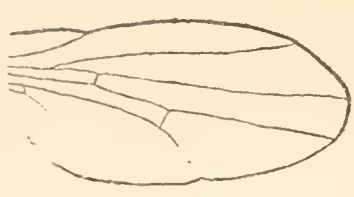

47

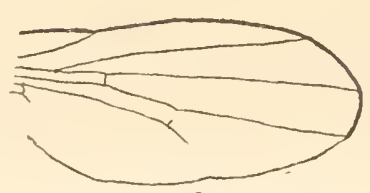

48

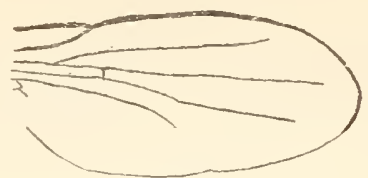

50

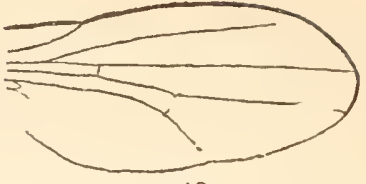

49

equaled in the classes where the two wings markedly differ, indicates a definite positive correlation.

Furthermore, when one wing is abnormal the chances that the other one will be abnormal also are 62 in 100 in the case of the males and 74 in 100 in the case of the females. This is an estimate based upon 4,000 pedigreed individuals. It will probably not hold for wild flies, since a large part of the 4,000 were from the abnormal strain; hence the estimated chances are larger than they would be in nature, because, as will be shown shortly, there is a close relation between the percentage of abnormal offspring in a family and the likelihood that an abnormal fly will be abnormal in both wings. It does, however, give an idea of the correlation which exists between the two wings with respect to the presence or absence of abnormal venation when such abnormalities are well fixed, and it brings out the further point that there is a sexual difference to be considered.

\section{SEXUAL DIMORPHISM.}

The females show a greater tendency to be abnormal than do the males, and, when abnormal, their abnormalities are, on the average, more intense than those of the males. The first of these points is illustrated in table 4 and fig. 51. Table 4 shows the percentage of abnormal males and females in 200 families. It will be noted that as the percentage of abnormal males increases the percentage of their sisters which are abnormal increases until the latter have become practically 100 per cent abnormal. Then, since they can go no further, their brothers gain on them in abnormality until we get families in which 100 per cent of both males and females are abnormal. In fig. 51 the crosses show the position of the mean percentage of abnormal sisters for each 10 per cent grade of abnormal brothers. A line is drawn to show the condition when for each per cent of male abnormality the female abnormality is 1.5 per cent. Thus, when 40 per cent of the males are abnormal, 60 per cent of their sisters are abnormal. Corresponding to 60 per cent male abnormality, we get 90 per cent female abnormality. Beyond that the females can go little further, hence the line becomes 
TABLE 4.-Percentage of abnormal males and females in 200 families.

Females

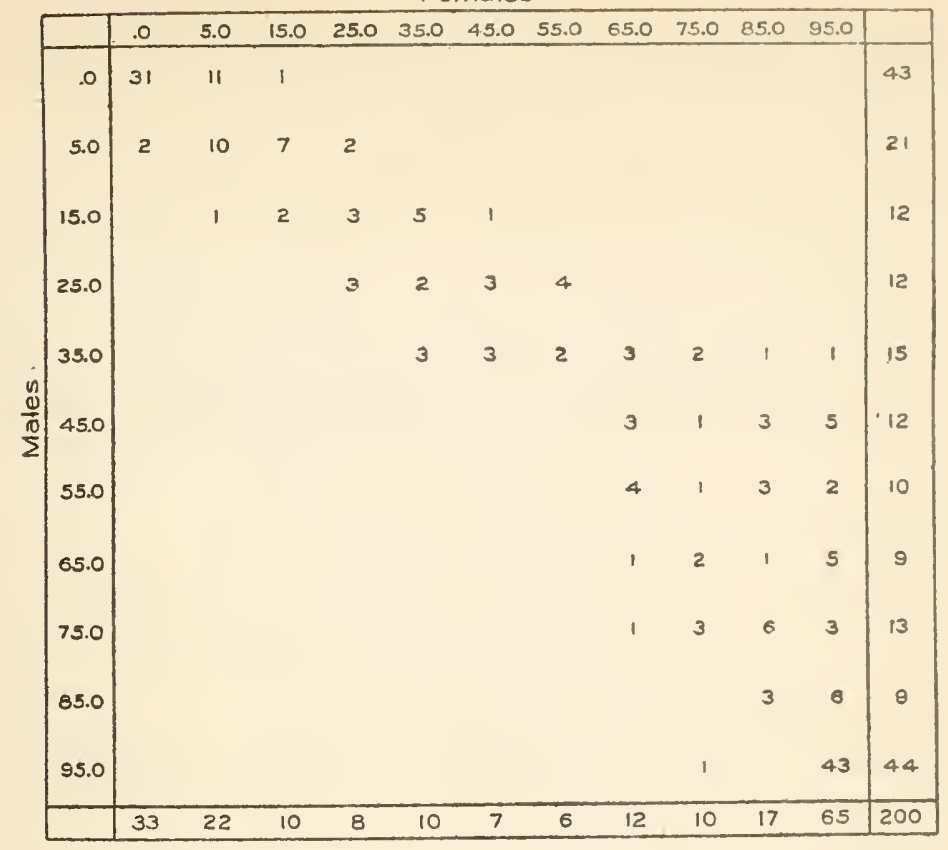

Females

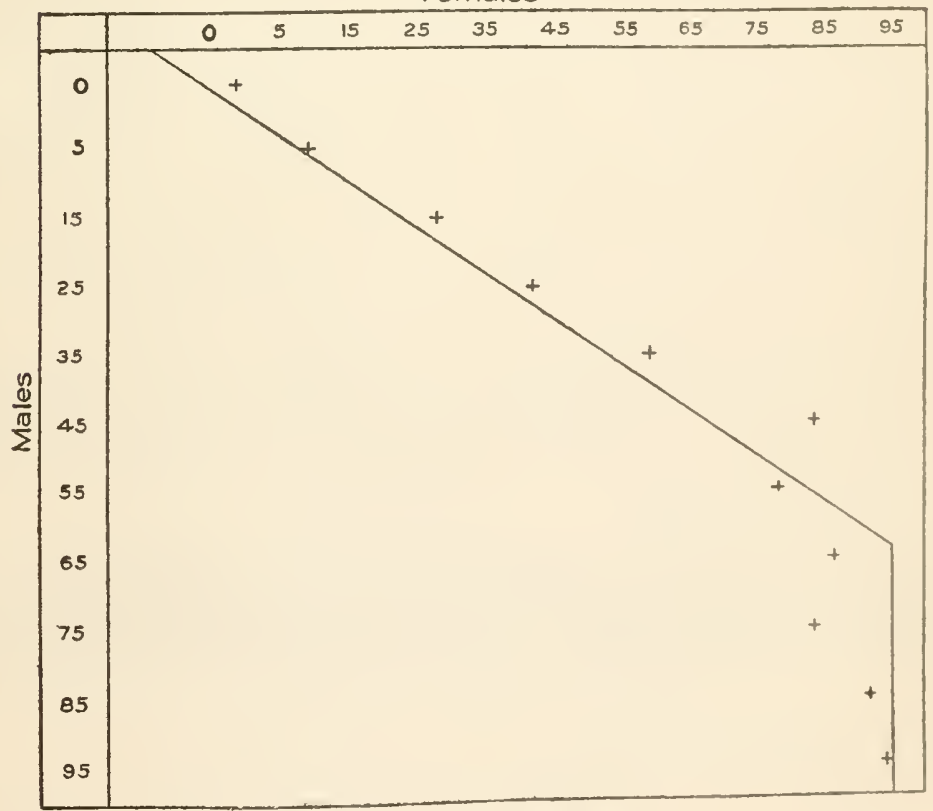

FIG. 51.-For explanation see p 8 . 
vertical. The close fit of this line to the observed data shows that the relation

Percentage of abnormal females $=1.5 \times$ percentage of abnormal males may be taken as approximately describing the average observed condition.

Owing to the impossibility of describing the intensity of abnormality in quantitative grades, we can not give a formula for showing its sexual relation. Tables 2 and 3 show that there is such a relation. The question as to whether both wings or only one shall be abnormal is also a part of this same problem of the variation of the intensity of the abnormality. We have seen that when a female is abnormal she will in 74 per cent of the cases be so abnormal that both wings will be affected, while only 62 per cent of her abnormal brothers will be abnormal in both wings.

THE RANGE OF VARIATION OF ABNORMALITY INCLUDES “NORMAL" VENATION.

One other point is to be noted. The intensity of abnormality ranges all the way from cases in which there is almost as much abnormal venation as normal down to a barely discernible deviation from normality. We have, then, in studying the inheritance of abnormal venation, the serious difficulty that a just indiscernible abnormality may be present.* Such a fly would be recorded as normal. Table 5 suggests that they would be more likely to occur in families in which the percentage of abnormal offspring is low, for as such percentage decreases the percentage of abnormal individuals which are abnormal on both sides (C. S.) decreases. In other words, there is an increasing percentage of abnormal flies which have the abnormality so reduced that in at least one wing it can not be seen. Hence, presumably, there is an increasing percentage of flies which have the abnormality reduced in both wings to a point just below visibility. These will be more common among males than among females, because the intensity of the abnormality is less in male than in female wings. Whether this alone accounts for the fact that a smaller percentage of brothers are visibly abnormal than of sisters is a question to which it is difficult to give an answer.

*May not this be true also of the spotted condition in certain mammals? A guineapig still behaves as a spotted animal even if the spots are reduced until only the eyes remain affected. If the variation goes still further we would have an animal germi"latly spotted, somatically spotless. We would then say that the spotted condition is 


\section{HISTORY OF THE PEDIGREED STRAIN.}

Before taking up the data concerning inheritance, it will be well to outline briefly the history of the chief pedigreed strains. Further details are given in table 36. Mating 211 was the first family in these lines of which a large number of offspring were described. Both parents were abnormal in both wings. The wings of 177 offspring of this mating were sketched. It was found that 31 per cent of the males were abnormal and 65 per cent of the females. Successive generations after this, breeding brother with sister, gave the following results: Abnormal female by normal male (mating 257), 70 per cent of each sex abnormal; abnormal female by abnormal male (mating 284), 62 per cent of the males and 96 per cent of the females abnormal; abnormal female by normal male (mating 330), 96 per cent of the males and 91 per cent of the females abnormal; abnormal female by normal male (mating 367), 64 per cent of the males and 91 per cent of the females abnormal. A number of matings were made from the offspring of No. 367 . Matings 405 and 408 are of especial interest.

In both of these matings both parents were abnormal in both wings. Unfortunately there were a small number of offspring from each (25 and 29, respectively), but all of the offspring of mating 405 were normal and all those of mating 408 were abnormal. Three matings were made from the offspring of 405 . Of the 385 offspring of these, not a single one showed the slightest trace of an abnormality, while of the 51 offspring of mating 440 (the parents being children of 408) only one, a male, was free from abnormal venation. Mating 405 , then, became the starting-point of the "normal strain" and mating 408 the starting-point of the "abnormal strain."

As can be seen from table 36 , the various generations of the abnormal strain gave approximately, sometimes actually, 100 per cent abnormal flies, although normal individuals were far from rare. Furthermore, the intensity of the abnormalities increased. The greatest abnormality noticed before the fifth generation is shown in fig. 20. Up to that time all abnormalities were confined to the second longitudinal vein. Beginning with the sixth generation, abnormalities appeared on the third longitudinal vein. They became frequent by the tenth generation. In the fifteenth generation they were common and abnormalities began to be noticed on the fourth longitudinal vein. These have, even yet, rarely exceeded small spurs near the distal end. About this time the fifth longitudinal vein also began to be affected, and specimens such as are illustrated in figs. 30 and 32 were found. Meanwhile increasingly great abnormalities on the second and third longitudinal veins occurred. (See figs. 37 to 42 for examples. The condition shown in fig. 43 is unique.)

Turning now to the normal strain, three points should be borne in mind: the parents in each generation were normal, it came from the same 
ancestry as the abnormal strain, and about one-third of 1 per cent of wild Drosophila ampelophila were found to be abnormal. For four generations after branching from the abnormal strain (five, counting mating 405) not a single abnormal individual was found, but in the next generation 1 fly out of 216 ( 0.5 per cent) had a very slight abnormality. In succeeding generations the percentage increased for a time, in spite of artificial selection to the contrary, and then diminished to zero under the same treatment. The abnormalities were all small, never greater than "medium." Table 6 summarizes the history of this strain for 40 generations.

TABLE 6.-Fluctuation in percentage of abnormal individuals in a normal strain.

\begin{tabular}{|c|c|c|c|c|c|c|c|}
\hline $\begin{array}{l}\text { Generations } \\
\text { of normal } \\
\text { strain. }\end{array}$ & $\begin{array}{c}\text { No. of } \\
\text { normal. }\end{array}$ & \multirow{2}{*}{$\frac{\begin{array}{c}\text { No. of } \\
\text { abnormal. }\end{array}}{0}$} & \multirow{2}{*}{$\begin{array}{c}\begin{array}{c}\text { Percentage } \\
\text { of } \\
\text { abormal. }\end{array} \\
0.0\end{array}$} & $\begin{array}{l}\text { Generations } \\
\text { of normal } \\
\text { strain. }\end{array}$ & $\begin{array}{c}\text { No of } \\
\text { normal. }\end{array}$ & $\begin{array}{c}\text { No. of } \\
\text { abnormal. }\end{array}$ & $\begin{array}{c}\text { Percentage } \\
\text { of } \\
\text { abnormal. }\end{array}$ \\
\hline 1 and 2 & 418 & & & 23 and 24 & 144 & 0 & 0.0 \\
\hline 34 & 235 & 0 & 0.0 & $25 \quad 26$ & & 0 & 0.0 \\
\hline 5 & 575 & 1 & 0.2 & & & 1 & 0. \\
\hline 7 & 594 & $\frac{1}{7}$ & 1.2 & 29 & 11 & 0 & 0.0 \\
\hline 9 & 336 & 31 & 8.4 & & & 0 & 0 \\
\hline 11 & 471 & 45 & 8.7 & 33 & 21 & 0 & 0.0 \\
\hline 13 & 183 & 14 & 7.1 & & 14 & 0 & 0.0 \\
\hline 15 & 79 & 2 & 2.5 & 37 & 55 & 0 & 0.0 \\
\hline 17 & 110 & 5 & 4.3 & 39 & 63 & 0 & 0.0 \\
\hline $\begin{array}{l}19 \\
21\end{array}$ & $\begin{array}{r}234 \\
56\end{array}$ & $\begin{array}{r}14 \\
2\end{array}$ & $\begin{array}{l}5.6 \\
3.4\end{array}$ & Total & 4,725 & 122 & 2.5 \\
\hline
\end{tabular}

It is to be noted that the percentage of abnormal individuals is greater in this strain artificially selected for normal venation than it is in nature. At first thought one would say that this is an effect of the environment to which they were subjected. If this be true, environment may have played a part in the production of the abnormal strains. I think, however, that it is not true. A sufficient explanation seems to lie in the fact that a form of selection exists in nature which is keener than the artificial sort, even when the latter is carried out under a lens.

THE EEFECT OF SELECTION.

Of late years there has arisen considerable skepticism concerning the cumulative effect of selection except as a means of isolating "pure lines." Jennings (1908) says: "Certainly, therefore, until some one can show that selection is effective within pure lines, it is only a statement of fact to say that all experimental evidence is against this." Whether or not the present material has a bearing upon the question thus clearly put depends upon the definition of a pure line. If a pure line be defined as one from which nothing else can be gotten by selection, further discussion is not necessary. On the other hand, if inbreeding (for the most part, brother $\times$ sister) for 10 or 15 generations and rigid selection (in this case, with respect to wing-venation) may be 
reasonably supposed to have established as "pure" a line as exists in a given case, the following facts may be of interest.

The abnormalities obtained, both in the direction of veins added and of veins lacking, far surpass those found in nature in this or any other insect with which I am familiar. Furthermore, they do not even remotely suggest the venation of any of this fly's relatives. Something new has been produced. In the strain whose early history has just been described there was, at the start, no definite effort made to build up an abnormal race as quickly as possible. Later I tried to do this from wild material obtained from other localities.

Starting with an abnormal male and a normal female from Boston and an abnormal male and female from Bloomsburg, Pennsylvania, I rigidly selected for additional veins. The record for each successive set of two generations was $8.8,5.5,11.5,14.3,30.3,45.8,85.9$, and 100 per cent abnormal. Thereafter mass-breeding was practiced and the abnormal strain preserved for about a year by merely starting a fresh jar every couple of weeks with the most abnormal individuals found at that time.

The abnormalities in this strain were of the same nature and extent as in the one started from the Long Island material. It would seem that this increase in the percentage of abnormal individuals up to 100 per cent and the subsequent increase of the intensity of the abnormalities can not be due to the gradual weeding out of all units but the one or several desired, because one quickly gets things which one can safely say did not exist in the population with which we started, or, to be more exact, which we do not see. Some can probably imagine that the "units" for each successive grade of abnormality existed in the parents with which we started, but that they were held in check by an equal number of inhibiting " units" of corresponding powers, so that the result could be explained by saying that in the selection we cut out step by step successively stronger inhibiting units, thus allowing successively greater abnormality-producing units to manifest themselves. On any other hypothesis, it seems to me, we must admit the cumulative effect of selection upon a "unit," $i$. $e$., within a pure line.

But, upon this hypothesis, how can we account for the occasional normal flies? Why do not the inhibiting units stay cut out after we have once gotten rid of them so thoroughly that all the flies of several successive generations show strong added veins? Perhaps they do stay cut out and these occasional normals are merely fluctuating variations in the abnormal unit. If so, and if selection does not have a cumulative effect within a unit, it would be impossible to return to normality from a series of inbred generations of abnormality. But it is possible. Starting with a family which had one normal offspring in a total of 133 (99.2 per cent abnormal) and selecting to reduce the extra veins, the percentage of abnormal offspring in successive generations was 81.8 , $66.2,32.9,12.5,17.0,0.0,0.0,0.0$, and so on, as a typical normal strain. 
The building up of an abnormal strain from a long-inbred normal one was also nearly completed when it was stopped by accident. I did not think it worth while to start it anew, as its accomplishment would prove little, since it might be said that the normal strain was a "mixed general population" due to normality (inhibiting) units masking all sorts of latent abnormality units.

In nature a small percentage of flies have the fifth longitudinal vein somewhat shortened (see fig. 47). This variation also appears in the experimental strains. Rather as a matter of curiosity, I selected for shortened veins during a few generations and very quickly obtained such specimens as are illustrated in figs. 48 to 50 . One can not go further in this direction without some special technique, because the wings, lacking the support of the veins, droop and catch in the fly's food. Probably breeding could be continued by cutting off the parent wings when matings are made. I did not try it, as it was already very evident that selection was just as effective in the negative as in the positive direction.

On the other hand, all attempts to fix, by selection, some particular type of abnormality utterly failed. It was thought possible that the great variety of forms which the extra veins showed was due to a mixture of a number of simple forms and that selection might isolate these simple types. The most hopeful was a simple forking of the second longitudinal vein (see fig. 10). Selection for this type was started several times, but never went beyond the fifth generation, because, although there were plenty of abnormal flies in each generation, there was no increase in the number showing this particular type, and sooner or later a generation would contain none of them from which to breed. The same was true in the experiments aimed to fix the abnormality on, for example, the third longitudinal vein, but to keep it off of the second. It is easy to have all the abnormal flies abnormal only on the second longitudinal vein, providing one be content with small abnormalities. However, as soon as one increases greatly, by selection, the abnormality on the second vein, the other veins begin to be abnormal.

These are the facts: Starting with slight extra veins, either in wild material or in material selected and inbred for normal venation, we can quickly get by selection 100 per cent abnormal offspring. In future generations this strain can be quickly brought back again to its normal condition by selection. Selection also quickly shortens the veins and would probably largely do away with them, provided some technique were adopted to keep the results of selection alive. But selection, accompanied by the strictest inbreeding (brother $x$ sister and parent $x$ child) failed to isolate any unit characterized by a given form or extent of abnormality.

The interpretation of these facts would doubtless vary with varying opinions as to unit-characters. 
THE DATA CONCERNING INHERITANCE.

Without reference to the grandparents, the data are summarized in table 7:

TABLE 7.

\begin{tabular}{|c|c|}
\hline Crosses. & $\begin{array}{l}\text { Average } \\
\text { p.ct. of } \\
\text { abnorinal } \\
\text { oftspring. }\end{array}$ \\
\hline $\begin{array}{l}\text { Normal } \times \text { normal } \ldots \ldots \ldots \ldots \ldots \ldots . . . . . . \\
\text { Abnormal male } \times \text { normal female... } \\
\text { Normal male } \times \text { abnormal female... } \\
\text { Abnormal } \times \text { abnormal ................... }\end{array}$ & $\begin{array}{r}9.6 \\
35.8 \\
54.7 \\
85.9\end{array}$ \\
\hline
\end{tabular}

In this work a fly is counted as abnormal if there is the slightest trace of abnormality in either wing. These results leave no room for doubt concerning the heritability of the tendency toward extra veins.

Tables 8 to 19 show the relation between various ancestors and the offspring. The coefficients of association found from these are given below the respective tables. Although these coefficients are greater than expectation on the basis of Pearson's Law of Ancestral Heredity, they do not negative his conclusions. He was very careful to exclude cases in which there is inbreeding or assortative mating. Both were largely practiced in these experiments. These coefficients do show, however, that change of sex in the ancestry does not uniformly weaken inheritance. Thus, the average coefficient of association between father and sons, and mothers and daughters (no change of sex) is 0.78 ; and that between father and daughters, mothers and sons (one change of

TABLE 8.

\begin{tabular}{|c|c|c|c|}
\hline & N. & A. & \\
\hline N. & 2919 & 837 & 3786 \\
\hline A. & 1241 & 1948 & 3189 \\
\hline & 4190 & 2785 & 6975 \\
\hline
\end{tabular}

C. A. $=0.694$.

TABLE 10.

\begin{tabular}{|r|r|r|r|}
\hline & N. & A. & \\
\hline N. & 2801 & 465 & 3266 \\
\hline A. & 1389 & 2320 & 3709 \\
\hline & 4190 & 2785 & 6975 \\
\hline
\end{tabular}

C. $\mathbf{A} .=0.819$.
TABLE 9.

DADGHTERS.

\begin{tabular}{|c|c|c|c|}
\hline & N. & A. & \\
\hline N. & 3011 & 1329 & 4340 \\
\hline A. & 951 & 2763 & 3714 \\
\hline & 3962 & 4092 & 8054 \\
\hline
\end{tabular}

C. $A .=0.736$.

TABLE 11.

\begin{tabular}{|c|c|c|c|}
\hline & N. & A. & \\
\hline N. & 2383 & 746 & 3729 \\
\hline A. & 979 & 3346 & 4325 \\
\hline & 3962 & 4092 & 5054 \\
\hline
\end{tabular}

C. $A .=0.864$. 
TABLE 12.

\begin{tabular}{|c|c|c|c|}
\hline & N. & A. & \\
\hline N. & 2813 & 1079 & 2892 \\
\hline A. & 1329 & 1705 & 3034 \\
\hline & 4142 & 2784 & 6926 \\
\hline
\end{tabular}

C. $A .=0.540$.

TABLE 14.

\begin{tabular}{|c|c|c|c|}
\hline \multicolumn{4}{|c|}{ sons. } \\
\hline \multirow{3}{*}{ 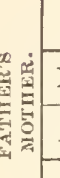 } & N. & A. & \\
\hline & 2535 & $18 \frac{1}{2}$ & 3019 \\
\hline & $160 \tau$ & 2300 & $390 \pi$ \\
\hline & 4142 & 2781 & 6926 \\
\hline
\end{tabular}

C. $\mathrm{A} .=0.765$.

TABLe 16.

\begin{tabular}{|c|c|c|c|}
\hline & N. & A. & \\
\hline N. & 2766 & 1015 & 3781 \\
\hline A. & 1339 & $1 \approx 61$ & 3100 \\
\hline & $\$ 105$ & 2766 & 6881 \\
\hline
\end{tabular}

C. $\mathrm{A} .=0.672$.

TABLE 18.

SONS.

\begin{tabular}{|c|c|c|c|}
\hline & N. & A. & \\
\hline N. & 2444 & $47 \%$ & 2921 \\
\hline A. & 1661 & 2299 & 3960 \\
\hline & 4105 & 2776 & 6881 \\
\hline
\end{tabular}

C. A. $=0.753$.
TABLE 13.

DACGHTERS

\begin{tabular}{|c|c|c|c|}
\hline & N. & A. & \\
\hline N. & 2602 & 1855 & 4457 \\
\hline A. & 1210 & 2228 & 3538 \\
\hline & 3912 & 4083 & 7995 \\
\hline
\end{tabular}

C. $\mathrm{A} .=0.409$.

TABLE 15.

DACGHTERS.

\begin{tabular}{|c|c|c|c|}
\hline & N. & A. & \\
\hline N. & $2 \% 27$ & 759 & 3486 \\
\hline A. & 1185 & 3324 & 4509 \\
\hline & 3912 & 4083 & $\tau 995$ \\
\hline
\end{tabular}

C. $A .=0.820$.

TABLE 17.

DALGIITERS.

\begin{tabular}{|c|c|c|c|}
\hline & N. & A. & \\
\hline N. & 2619 & 1768 & 4387 \\
\hline A. & 1262 & 2296 & 3558 \\
\hline & 3881 & 4064 & 7945 \\
\hline
\end{tabular}

C. A. $=0.459$.

TABLE 19.

DAUGIITERS.

\begin{tabular}{|c|c|c|c|}
\hline & N. & A. & \\
\hline N. & 2630 & 741 & 3371 \\
\hline A. & 1251 & 3323 & 4574 \\
\hline & 3881 & 4061 & 7945 \\
\hline
\end{tabular}

C. A. $=0.808$.

sex) is also 0.78. Considering the grandparents, the average coefficient of association between sons and father's father, and daughters and the mother's mother (no change of sex) is 0.67 , while that between sons and the mother's father, and daughters and the father's mother (two changes of sex) is 0.74. This result agrees with that of Blanchard (1903) concerning the coat-color of horses and is not in harmony with Pearson's (1900) and the writer's (1903) concerning the eye-color in man. 
there been any apparent tendency to settle down to any definite type.* The "center of disturbance" has remained in the distal portion of the marginal cell closely related to the second longitudinal vein. Next to the second, the third vein has been the most affected, then the fifth; but I have failed to fix the abnormalities in these veins. They are, apparently, all the effects of the disturbing factor or factors, centered on the second longitudinal vein in the marginal cell.

The hundreds of families studied showed that it is impossible to predict, from the character of the ancestors, what the form of the abnormality will be in the offspring. The most that one can do is to give an approximate estimate of the percentage of abnormal individuals and a still less exact prediction of the average intensity of the abnormalities.

\section{THE BEARING OF THESE DATA UPON PROPOSED LAWS OF HEREDITY.}

In my former paper (1907) I considered that normal venation is more or less dominant over abnormal in the Mendelian sense. Such was the case in the early part of the work, although, as was pointed out, it was the spirit only and not the letter of the law which was followed. When a normal fly, having normal ancestors, was crossed with an abnormal one, practically all the offspring were normal. The abnormalities which did appear were slight, but there was no doubt about their presence. Matings 318 to 322 (see table 36) illustrate such cases. The offspring of matings 347 to 353 are second-generation hybrids from such a cross. They show a condition not very divergent from the Mendelian expectation.

Since the number of offspring in most of the families considered here is large, the Galtonian formula can be tested in single families, and it is evidently not at all in accord with the data. Neither is Pearson's modification of it. The fact that normal $\times$ abnormal gave, in large families, practically all normal completely negatives for these data all theories which are founded on the hypothesis of equipotency of the two parental characters.

On the other hand, while the results of certain matings accord with Mendelian expectation, the fit is far from good in the majority even in the early generations. For instance, we have seen that neither normal nor abnormal breeds true. A Mendelian recessive would be expected to do so ; therefore we can not consider either normality or abnormality to be Mendelian unit-characters in that sense.

\footnotetext{
*Here again (see p. 10) the similarity to the experience of breeders of spotted animals is interesting. Castle (1905), for example, found that "one can by selection progress in either direction through this series of changes, either increasing or decreasing the number and extent of the pigment patches, but it is impossible without long-continued selection to fix the color-pattern at any particular stage in the series; perhaps it is wholly impossible to do so, as Cuénot (1904) asserts on the basis of his studies on mice, but this I very much doubt."
} 
Fig. 52 shows graphically the results of the three sorts of matings: normal $\times$ normal, normal $\times$ abnormal, and abnormal $\times$ abnormal. The first should give one mode at zero abnormality and another at 25 per cent abnormality on the assumption that normality is dominant in the sense in which the term is now used in Mendelian literature. These modes would represent the results of $\mathrm{DD} \times \mathrm{DD}$ and $\mathrm{DR} \times \mathrm{DR}$, respectively. They are present, but the curve runs all the way up to 65 per cent abnormal. The second should give one mode at zero and another at 50 per cent, representing the results of $\mathrm{DD} \times \mathrm{RR}$ and $\mathrm{DR} \times \mathrm{RR}$, respectively. The mode at 5 per cent is marked and might be explained as the

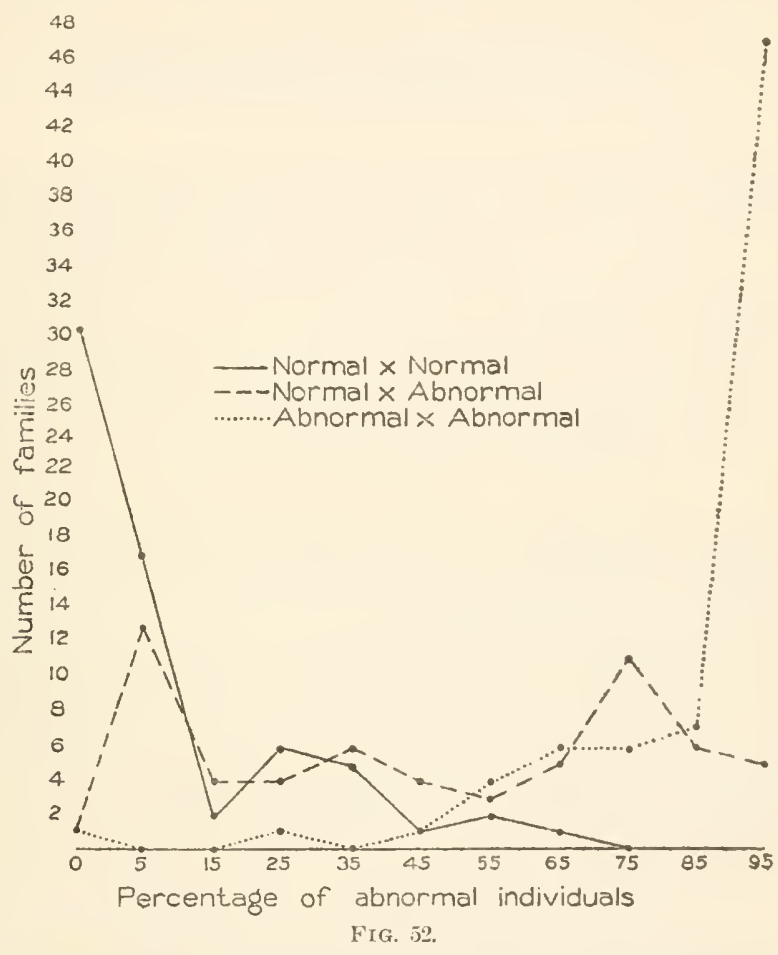

result of "incomplete dominance," a thing which is itself badly in need of a Mendelian explanation. At 50 per cent there is a drop in the curve where there should be a mode. There is a strong mode at 75 per cent, where there should be none. This is true both when the male is the normal parent and when the male is the abnormal one (see fig. 53). Abnormal $\times$ abnormal should have but a single mode, 100 per cent (or 95 per cent as the figure is drawn), representing the result of $\mathrm{RR} \times \mathrm{RR}$. Such a mode is pronounced in the curve, being chiefly made up of the families of the abnormal strain after generation VIr, but the curve reaches all the way to zero.

These data are analyzed in tables 24 to 35 , so that there is no need of a further text description of them. They are taken from the early part 
of the work. The results of the seven crosses between the abnormal and normal strains in the fifty-ninth generation-all that were made at that time-are of interest in this connection and are shown in table 23.

Any theory applied to these data must accord with the following facts:

(1) Abnormalities occasionally appear in the venation of the wings of wild Drosophila ampelophila. These are usually added veins. Since evolution in the Diptera has been accompanied by a reduction in the number of veins, these abnormalties are of the nature of "reversions." The tendency to produce extra veins is inherited and has been increased by selection. This is also true of the tendency to shortening of veins.

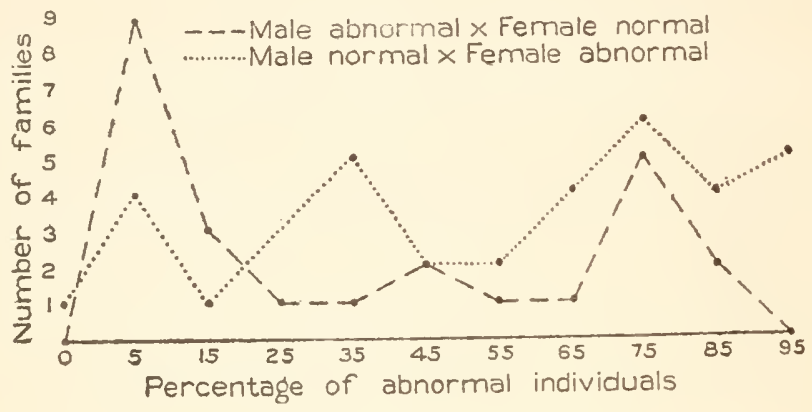

FIG. 53 .

An examination of more than 50,000 abnormal wings has revealed an immense diversity of forms which the abnormality assumes. Not only are new forms being constantly discovered, but the intensity of the abnormality has constantly increased as long as selection for that end has been kept up. The limit of the increase was apparently not reached, but the extra veins have always been very crude, only rarely assuming a form and position comparable to ordinary veins.

(2) A greater percentage of females than of males is abnormal. The formula

Percentage of abnormal sisters $=1.5 \times$ percentage of abnormal brothers approximately describes the average condition in the various families. Attempts to change significantly this relation have failed, and seem destined to fail, for change of sex in the ancestry does not weaken inheritance.

(3) The lower range in the variation of abnormality certainly includes barely discernible deviations from normality and presumably just indiscernible deviations also. The latter would be considered normal.

(4) Frequently one wing of a fly is abnormal, the other not visibly so. There is a direct relation between the percentage of abnormal offspring of a given mating which are abnormal in both wings and the total percentage of abnormal offspring. Furthermore, on the average, parents which are abnormal in both wings give a larger percentage of abnormal 
offspring than those which are abnormal in one wing only. There is no relation between parents and offspring with respect to the side upon which asymmetrical abnormalities occur. There is a correlation between the two wings of individual flies with respect to the intensity of the abnormality.

(5) Normal male $\times$ abnormal female gives a greater percentage of abnormal offspring than the reciprocal cross.

(6) Not only has the abnormality increased in the abnormal strain, but, in spite of artificial selection to the contrary, an increasingly large number of abnormal individuals appeared for a while in the normal strain and then with the same treatment the percentage again decreased. When the flies are allowed to choose their own mates the percentage of abnormals is kept low even when abnormal flies are added from time to time.

(7) Abnormality originally behaved somewhat like a Mendelian recessive, but in the later generations departed, in its behavior, very far from that theory as it is now understood.

There would be little profit in reviewing the various modifications of the simple Mendelian formula and pointing out in detail why they are not satisfactory in the present case. I have tried most, if not all, of those which have been proposed and also a number of original hypotheses involving two or more allelomorphs. All these attempts have been failures with the exception of the idea of variation of potency (Lutz, 1907). If sufficiently elaborated this will "explain" each of the conditions set forth above, and until quite recently I believed that the inheritance of the abnormal venation followed this modification of the Mendelian law. It seemed quite probable that there was a single pair of allelomorphs involved-the abnormality-producing factor and its absence - but that the strength of the positive one varied, and that these variations were inherited, making the problem a combination of the inheritance of a fluctuation variate and of Mendelian segregation (Lutz, 1908). In my report at the time of finishing the work at Cold Spring Harbor I even constructed hypothetical curves for this variation. However, I have since realized that the "explanation" of conditions 6 and 7 was very weak. It was "that in selecting parents to continue the normal strain I merely selected flies having no extra veins. For the most of the time the work of describing offspring was unaroidably so far behind the breeding-work that I did not know what percentage of their brothers and sisters were abnormal. Hence I had no way of judging as to the germinal constitution of the parents. The normal strain is probably a mixture of flies lacking the abnormal factor (might be called NN's) and of flies which have it in hybrid condition of weak allelomorphic strength (NA's). In generations VII to XXII I was probably unconsciously breeding from these NA's. This is an answer to the first part of condition 6 . 
"We have, now, only to take up the fact that in inheritance these abnormalities follow the spirit but not the letter of the Mendelian law (condition 7). We might consider that the dominance of normal over. abnormal is merely due to the dilution of the abnormality-producing factor in the NA's. If it is strong it may be potent enough to produce abnormalities in spite of this dilution, thus giving incomplete dominance. Even when it is pure (AA), its fluctuation may give individuals in which the zygotic strength is not great enough to produce abnormalities, thus accounting for the normals in the abnormal strain. Whether one could so increase the strength of the abnormality-producing factor that when the selected flies are mated with flies lacking the factor

TABLE 23.-Results of seven crosses between abnormal and normal strains in a late generation.

\begin{tabular}{|c|r|r|c|}
\hline $\begin{array}{c}\text { Mating } \\
\text { Nu. }\end{array}$ & $\begin{array}{c}\text { Ab- } \\
\text { normal. }\end{array}$ & Total. & $\begin{array}{c}\text { Per cent } \\
\text { abnormal. }\end{array}$ \\
\cline { 1 - 3 } $2561 \ldots \ldots \ldots$. & 43 & 113 & 38.1 \\
$2562 \ldots \ldots \ldots .$. & 42 & 126 & 33.3 \\
$2629 \ldots \ldots \ldots$. & 65 & 130 & 50.0 \\
$2630 \ldots \ldots \ldots$. & 47 & 79 & 59.5 \\
$2631 \ldots \ldots \ldots$. & 21 & 28 & 75.0 \\
$2633 \ldots \ldots \ldots$. & 19 & 27 & 70.4 \\
$2645 \ldots \ldots \ldots$. & 14 & 24 & 58.3 \\
\hline Total... & 251 & 527 & 47.6 \\
\hline
\end{tabular}

all the offspring will be abnormal is not certain, but table 23 indicates such a possibility."

If, however, we have, in carefully conducted experiments, many flies somatically normal but germinally abnormal, and if by selection it is easy to so weaken the abnormality-producing factor that from a strain 100 per cent abnormal we get and keep one 100 per cent somatically normal (all presumably germinally abnormal, since they came from a 100 per cent abnormal strain), must we not admit the possibility that all somatically normal flies have the germinal possibilities of abnormality? This makes the problem much simpler, as, leaving out the question of Mendelian segregation, we have only to consider the inheritance of the variations of an abnormality-producing factor, whatever that may be. Let us take up the seven conditions which must be satisfied.

Condition 1. - All flies possess the abnormality-producing factor in the germ. It is usually so weak that it has no visible effect upon the soma. Occasionally, however, it is strong enough to do so, and its strength can be so increased by selection that it always does so.

Condition 2. - It is necessary to suppose that it takes a greater strength of the germinal factor to have a visible effect upon the male soma than upon the female. This sexual difference of developmental physiology is quite common and the hypothesis will doubtless be readily allowed by most critics in this case. It is interesting to wonder whether the possession of horns by certain male ungulates, while the females lack them, is an extreme example of this same phenomenon.

Condition 3. - To be expected on this hypothesis.

Condition 4.-The explanation here would differ according to different notions of the mechanies of heredity. If we accept the apparently most 
favored notion that there is some specific substance in the germ which produces the character in question and which is divided at the celldivision which separates the substances forming the right side from those forming the left side of the complete soma, it would be difficult to believe the division is always, or in most cases, exactly even. If it is not with respect to the abnormality-producing factor, it would give rise to the phenomenon of asymmetry as to the extent of the abnormality. Only when the factor is rather weak to start with would this deviation from exact equality of division frequently result in the share going to one wing being so small that that wing would be normal while the other wing is abnormal; hence there would be a correlation between the degree of the abnormality and the phenomenon of one wing being normal while the other is abnormal (see p. 5). The approximate equality of the apportionment of the factor in division may be taken as the explanation of the correlation in the intensity of the abnormality in the two wings, and the degree of this correlation is a measure of the degree of equality of the division. Since the going of a slightly greater strength to the right side than to the left, or vice versa, is a mere accident in development, it is not to be expected that there will be an inheritance of a particular side getting the greater strength (see p. 17). But since flies abnormal in only one wing came from germs which had a weak abnormality-producing factor, it is to be expected that the germs they produce will be weak with respect to this factor, and so a smaller percentage of their offspring will be abnormal than of the offspring of parents abnormal in both wings (see p. 17).

Condition 5. - Since it takes a greater strength of the germinal factor to produce abnormalities in the males than in the females, a male somatically normal may be produced by and produce germs containing as strong or stronger abnormality factors than a female which is somatically abnormal. Hence, in the long run, normal male $\times$ abnormal female will give more abnormal offspring than abnormal male $\times$ normal female, because in the latter cross one of the parents (the female) necessarily has the factor very weak.

Condition 6.- "In selecting parents to continue the normal strain, I merely selected flies having no extra veins. For the most of the time the work of describing offspring was unavoidably so fal behind the mating work that I did not know what percentage of their brothers and sisters were abnormal. Hence I had no way of judging as to the germinal constitution of the parents." Being unable, by examination of the soma, to tell the exact strength of the germinal content, I unconsciously used as parents flies in which the abnormality-producing factor was relatively strong, and thus started and for a time maintained a strain giving a relatively large number of abnormal flies. When the flies were allowed to do their own selecting of mates they were more successful (see p. 36). 
Condition \%.-From all we know of the inheritance of fluctuating variations, the mating of one grade with another will give variations about a mid-grade. If it takes a certain grade or strength of the germinal factor to produce a somatic effect and we mate a low grade (somatically normal) with one just sufficient to produce somatic abnormalities, the variations about the mid-grade will, in most cases, be too low to produce visible abnormalities. In other words, normality will dominate over abnormality. If, however, the parents are such that the grades of the offspring are about that required to produce somatic effects, the dominance will be imperfect. The abnormality will appear to be obeying “the spirit of the Mendelian law," but it will naturally " pay little attention to the letter of the simple law or any of the modifying clauses," especially in the latter generations, where the abnormal strain had the germinal factor much strengthened by selection.

It seems to me, then, that if we accept the notion of some specific factor in the germ which brings about the details of the characters of the soma the facts here discussed may be considered to be the result of the action of a factor present in all germs. The strength of this factor varies, and when of a certain strength produces certain visible effects. The partial dominance of normal over abnormal is due to the mean condition of the factor in the offspring of

(flies with factor strong enough to produce extra veins) $\times$ (flies with factor weak)

usually being below the strength required to produce abnormality.

I have not taken up the resemblance of the behavior of these abnormalities to that of "ever-sporting varieties," because I feel that classing these as such would not be a step toward an explanation. It would merely be naming the difficulty. It is also not the intention to imply that this hypothesis would apply to those other cases which are troublesome from a Mendelian standpoint and to which the principle of varying potency of Mendelian determiners has been applied (for example, Davenport, 1910). It seems not only possible but probable that many apparently non-Mendelian cases may be explained as a combination of alternative and blending inheritance (Lutz, 1908). But a simpler and more probable explanation of these data, provided we accept the somewhat dubious "germinal factor" idea, seems to be that we are dealing. here solely with a fluctuating character - the strength of the abnormalityproducing factor - and that the study of its inheritance is made difficult, if not largely impossible, by the fact that only in the upper part of its range can we judge of the relative values of this variable, for in the lower part its effects are invisible. 
TABLE 24.-Percentage of abnormal offspring in 48 matings of $N_{\xi}\left(e x . N_{\delta} \times N_{\xi}\right) \times N_{\uparrow}(e x . N \delta \times N \xi)$.

\begin{tabular}{|r|r|r|r|r|r|r|r|r|r|r|r|}
\hline & 0 & 5 & 15 & 25 & 35 & 45 & 55 & 65 & 75 & 85 & 95 \\
\hline 0 & 26 & 8 & 1 & & & & & & & & \\
\hline 5 & & 4 & 1 & & & & & & & & \\
\hline 15 & & & 1 & & 1 & 1 & & & & & \\
\hline 25 & & & & 1 & 2 & 1 & 1 & & & & \\
\hline 35 & & & & & & & & & & & \\
\hline 45 & & & & & & & & & & & \\
\hline 55 & & & & & & & & & & & \\
\hline 65 & & & & & & & & & & & \\
\hline 75 & & & & & & & & & & & \\
\hline 85 & & & & & & & & & & & \\
\hline 95 & & & & & & & & & & & \\
\hline
\end{tabular}

TABLE 25.-Percentage of abnormal offspring in 5 matings of

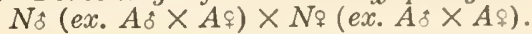

\begin{tabular}{|r|r|r|r|r|r|r|r|r|r|r|r|}
\hline & 0 & 5 & 15 & 25 & 35 & 45 & 55 & 65 & 05 & 85 & 95 \\
\hline 0 & 3 & & & & & & & & & & \\
\hline 5 & 1 & 1 & & & & & & & & & \\
\hline 15 & & & & & & & & & & & \\
\hline 25 & & & & & & & & & & & \\
\hline 35 & & & & & & & & & & & \\
\hline 45 & & & & & & & & & & & \\
\hline 55 & & & & & & & & & & & \\
\hline 65 & & & & & & & & & & & \\
\hline 75 & & & & & & & & & & & \\
\hline 85 & & & & & & & & & & & \\
\hline 95 & & & & & & & & & & & \\
\hline
\end{tabular}


TABLE 26.-Percentage of abnormal offspring in 6 matings of

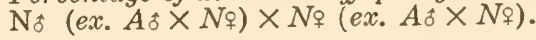

\begin{tabular}{|r|r|r|r|r|r|r|r|r|r|r|r|}
\hline & 0 & 5 & 15 & 25 & 35 & 45 & 55 & 65 & 75 & 85 & 95 \\
\hline 0 & & & & & & & & & & & \\
\hline 5 & & & 1 & & & & & & & & \\
\hline 15 & & & 1 & 2 & & & & & & & \\
\hline 25 & & & & 1 & & 1 & & & & & \\
\hline 35 & & & & & & & & & & & \\
\hline 45 & & & & & & & & & & & \\
\hline 55 & & & & & & & & & & & \\
\hline 65 & & & & & & & & & & & \\
\hline 75 & & & & & & & & & & & \\
\hline 85 & & & & & & & & & & & \\
\hline 95 & & & & & & & & & & & \\
\hline
\end{tabular}

TABLE 27.-Percentage of abnormal offspring in 4 matings of

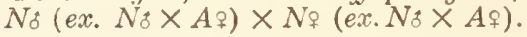

\begin{tabular}{|r|l|l|l|l|l|l|l|l|l|l|l|}
\hline & 0 & 5 & 15 & 25 & 35 & 45 & 55 & 65 & 75 & 85 & 95 \\
\hline 0 & 1 & & & & & & & & & & $\ddots$ \\
\hline 5 & & & & & & & & & & & \\
\hline 15 & & & & & & & & & & & \\
\hline 25 & & & & & & & & & & & \\
\hline 35 & & & & & & 1 & & & 1 & & \\
\hline 45 & & & & & & & & 1 & & & \\
\hline 55 & & & & & & & & & & & \\
\hline 65 & & & & & & & & & & & \\
\hline 75 & & & & & & & & & & & \\
\hline 85 & & & & & & & & & & & \\
\hline 95 & & & & & & & & & & & \\
\hline
\end{tabular}


TABLE 28. - Percentage of abnormal offspring in 5 mating 8 of

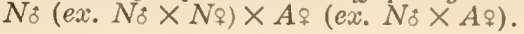

\begin{tabular}{|r|r|r|r|r|r|r|r|r|r|r|r|}
\hline & 0 & 5 & 15 & 25 & 35 & 45 & 55 & 65 & 75 & 85 & 95 \\
\hline 0 & 1 & & & & & & & & & & \\
\hline 5 & & 1 & 1 & & & & & & & & \\
\hline 15 & & & & & & & & & & & \\
\hline 25 & & & & & & & & & & & \\
\hline 35 & & & & & 1 & & & & & & \\
\hline 45 & & & & & & & & & 1 & & \\
\hline 55 & & & & & & & & & & & \\
\hline 65 & & & & & & & & & & & \\
\hline 75 & & & & & & & & & & & \\
\hline 85 & & & & & & & & & & & \\
\hline 95 & & & & & & & & & & & \\
\hline
\end{tabular}

TABLE 29. - Percentage of abnormal offspring in 7 matings of

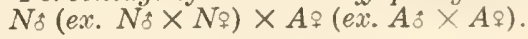

\begin{tabular}{|r|r|r|r|r|r|r|r|r|r|r|r|}
\hline & 0 & 5 & 15 & 25 & 35 & 45 & 55 & 65 & 75 & 85 & 05 \\
\hline 0 & & 1 & & & & & & & & & \\
\hline 5 & & & & 1 & & & & & & & \\
\hline 15 & & & & & 1 & & & & & & \\
\hline 25 & & & & 1 & & 1 & & & & & \\
\hline 35 & & & & & 1 & 1 & & & & & \\
\hline 45 & & & & & & & & & & & \\
\hline 55 & & & & & & & & & & & \\
\hline 65 & & & & & & & & & & & \\
\hline 75 & & & & & & & & & & & \\
\hline 85 & & & & & & & & & & & \\
\hline 95 & & & & & & & & & & & \\
\hline
\end{tabular}


TABLE 30.-Percentage of abnormal offspring in 19 matings

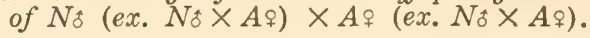

\begin{tabular}{|r|l|l|l|l|l|l|l|l|l|l|l|}
\hline & 0 & 5 & 15 & 25 & 35 & 45 & 55 & 65 & 75 & 85 & 95 \\
\hline 0 & & & & & & & & & & & \\
\hline 5 & & & & & & & & & & & \\
\hline 15 & & & & & & & & & & & \\
\hline 25 & & & & & & & 1 & & & & \\
\hline 35 & & & & & & 1 & & 1 & 1 & & \\
\hline 45 & & & & & & & & & & 1 & 2 \\
\hline 55 & & & & & & & & & & & 1 \\
\hline 65 & & & & & & & & & & & 2 \\
\hline 75 & & & & & & & & & & 1 & \\
\hline 85 & & & & & & & & & & 1 & \\
\hline 95 & & & & & & & & & 1 & & \\
\hline
\end{tabular}

TABLE 31. - Percentage of abnormal offspring in 9 matings of $N$ ô $(e x, A$ 字 $\times A$ 우 $) \times A$ \& $(e x . A \& \times A$ 우 $)$.

\begin{tabular}{|c|c|c|c|c|c|c|c|c|c|c|c|}
\hline & 0 & 5 & 15 & 25 & 35 & 45 & 55 & 65 & 75 & 85 & 95 \\
\hline 0 & & & & & & & & & & & \\
\hline 5 & & & & & & & & & & & \\
\hline 15 & & & & & & & & & & & \\
\hline 25 & & & & & & & & & & & \\
\hline 35 & & & & & & & & & & & \\
\hline 45 & & & & & & & & & & & 1 \\
\hline 55 & & & & & & & & & & 1 & \\
\hline 65 & & & & & & & & & & & \\
\hline 75 & & & & & & & & 1 & & 1 & \\
\hline 85 & & & & & & & & & & & 1 \\
\hline 95 & & & & & & & & & & & 4 \\
\hline
\end{tabular}


TABLE 32.-Percentage of abnormal offspring in 6 matings of

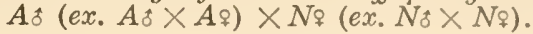

\begin{tabular}{|r|r|r|r|r|r|r|r|r|r|r|r|}
\hline & 0 & 5 & 15 & 25 & 35 & 45 & 55 & 65 & 75 & 85 & 95 \\
\hline 0 & & & & & & & & & & & \\
\hline 5 & 1 & 3 & 1 & & & & & & & & \\
\hline 15 & & & & & & & & & & & \\
\hline 25 & & & & & & & & & & & \\
\hline 35 & & & & & & & & & & & \\
\hline 45 & & & & & & & & & & & \\
\hline 55 & & & & & & & & & & & \\
\hline 65 & & & & & & & & & 1 & & \\
\hline 75 & & & & & & & & & & \\
\hline 85 & & & & & & & & & & & \\
\hline 95 & & & & & & & & & & & \\
\hline
\end{tabular}

TABLE 33.-Percentage of abnormal offspring in 12 matings

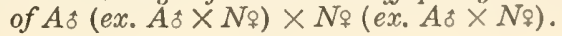

\begin{tabular}{|r|l|l|l|l|l|l|l|l|l|l|l|}
\hline & 0 & 5 & 15 & 25 & 35 & 45 & 55 & 65 & 75 & 85 & 95 \\
\hline 0 & & 1 & & & & & & & & & \\
\hline 5 & & 1 & 1 & & & & & & & & \\
\hline 15 & & & & 1 & & & & & & & \\
\hline 25 & & & & & & & 1 & & & & \\
\hline 35 & & & & & 1 & & & & & & \\
\hline 45 & & & & & & & & & & & \\
\hline 55 & & & & & & & & 1 & & & \\
\hline 65 & & & & & & & & & & 1 & \\
\hline 75 & & & & & & & & & 2 & 1 & 1 \\
\hline 85 & & & & & & & & & & & \\
\hline 95 & & & & & & & & & & & \\
\hline
\end{tabular}


TABLE 34.-Percentage of abnormal offspring in 21 matings

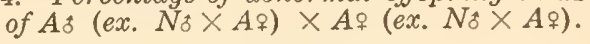

\begin{tabular}{|c|c|c|c|c|c|c|c|c|c|c|c|}
\hline & 0 & 5 & 15 & 25 & 35 & 45 & 55 & 65 & 75 & 85 & 95 \\
\hline 0 & 1 & & & & & & & & & & \\
\hline 5 & & & & & & & & & & & \\
\hline 15 & & & & & & & & & & & \\
\hline 25 & & & & & & & & & & & \\
\hline 35 & & & & & & & & 2 & & 1 & 1 \\
\hline 45 & & & & & & & & & & 2 & 1 \\
\hline 55 & & & & & & & & 1 & & 2 & 1 \\
\hline 65 & & & & & & & & 1 & & & 2 \\
\hline 75 & & & & & & & & & & 1 & 2 \\
\hline 85 & & & & & & & & & & & \\
\hline 95 & & & & & & & & & & & 3 \\
\hline
\end{tabular}

TABLE 35.-Percentage of abnormal offspring in 45 matings

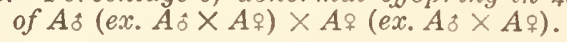

\begin{tabular}{|r|c|c|c|c|c|c|c|c|c|c|c|}
\hline & 0 & 5 & 15 & 25 & 35 & 45 & 55 & 65 & 75 & 85 & 95 \\
\hline 0 & & & & & & & & & & & \\
\hline 5 & & & & & & & & & & & \\
\hline 15 & & & & & & & & & & & \\
\hline 25 & & & & & & & & & & & \\
\hline 35 & & & & & & & & & & & \\
\hline 45 & & & & & & & & & & & \\
\hline 55 & & & & & & & & 1 & & & \\
\hline 65 & & & & & & & & & & & 1 \\
\hline 75 & & & & & & & & & & 1 & \\
\hline 85 & & & & & & & & & & 1 & 5 \\
\hline 95 & & & & & & & & & & & 36 \\
\hline
\end{tabular}


TABLE 36.-Percentage of abnormal offspring of 200 families.

\begin{tabular}{|c|c|c|c|c|c|c|c|}
\hline \multirow{3}{*}{$\begin{array}{c}\text { Mating } \\
\text { No. }\end{array}$} & \multirow{2}{*}{\multicolumn{2}{|c|}{ Parents. }} & \multicolumn{5}{|c|}{ Ofispring. } \\
\hline & & & \multicolumn{2}{|c|}{ Male. } & \multicolumn{2}{|c|}{ Female. } & \multirow{2}{*}{$\begin{array}{c}\text { Total } \\
\text { 1) ct. } \\
\text { abnormal. }\end{array}$} \\
\hline & Father. & Nother. & $\begin{array}{l}N_{0} \\
\text { recorded. }\end{array}$ & $\begin{array}{c}\text { P. ct. } \\
\text { abnormal. }\end{array}$ & $\begin{array}{l}\text { No. } \\
\text { recorded. }\end{array}$ & $\begin{array}{c}\text { P. ct. } \\
\text { abnormal. }\end{array}$ & \\
\hline 211 & A 205 & A 205 & 75 & 30.7 & 102 & 64.7 & 50.3 \\
\hline 214 & N 205 & N 205 & 39 & 30.8 & 34 & 47.1 & 38.4 \\
\hline 220 & A 207 & N 207 & 11 & 0.0 & 8 & 0.0 & 0.0 \\
\hline 226 & A 205 & A 205 & 69 & 46.4 & 77 & 80.5 & 64.4 \\
\hline 230 & A 205 & A 210 & 38 & 84.2 & 27 & 85.2 & 84.6 \\
\hline 233 & A 210 & A 210 & 31 & 71.0 & 25 & 76.0 & 73.2 \\
\hline 238 & A 210 & A 210 & 22 & 36.4 & 23 & 52.2 & 44.4 \\
\hline 239 & N 211 & N 210 & 29 & 51.7 & 29 & 69.0 & 60.3 \\
\hline 241 & N216 & N 216 & 61 & 0.0 & 69 & 0.0 & 0.0 \\
\hline 242 & $\mathrm{~N} 216$ & $\mathrm{~N} 216$ & 55 & 0.0 & 63 & 3.2 & 1.7 \\
\hline 243 & N 214 & N 214 & 64 & 28.1 & 57 & 36.8 & 32.2 \\
\hline 245 & N 215 & N215 & 20 & 20.0 & 14 & 42.9 & 29.4 \\
\hline 246 & N 215 & N215 & 27 & 25.9 & 31 & 32.3 & 29.3 \\
\hline 247 & N 215 & N 215 & 37 & 29.7 & 27 & 40.7 & 34.4 \\
\hline 253 & $\mathrm{~N} 220$ & N220 & 13 & 0.0 & 16 & 0.0 & 0.0 \\
\hline 257 & N 211 & A 211 & 87 & 70.1 & 90 & 70.0 & 70.0 \\
\hline 258 & $\mathrm{~N} 211$ & A 211 & 47 & 93.6 & 63 & 96.8 & 95.5 \\
\hline 259 & N 211 & A 211 & 21 & 47.6 & 35 & 94.3 & 76.8 \\
\hline 273 & $\mathrm{~N} 242$ & N 242 & 10 & 0.0 & 16 & 0.0 & 0.0 \\
\hline 276 & A 246 & N246 & 18 & 11.1 & 23 & 34.8 & 24.4 \\
\hline 278 & N 246 & N 246 & 16 & 25.0 & 17 & 58.8 & 42.4 \\
\hline 280 & $\mathrm{~N} 253$ & N 253 & 10 & 0.0 & 20 & 0.0 & 0.0 \\
\hline 281 & N 253 & $\mathrm{~N} 253$ & 37 & 2.7 & 52 & 1.9 & 2.2 \\
\hline 283 & A 257 & A 257 & 47 & 38.3 & 54 & 83.3 & 62.4 \\
\hline 284 & A 257 & A 257 & 77 & 62.3 & 91 & 95.6 & 80.4 \\
\hline 285 & N 257 & A 257 & 72 & 43.1 & 72 & 94.4 & 68.8 \\
\hline 286 & A 257 & A 257 & 34 & 44.1 & 36 & 88.9 & 67.1 \\
\hline 288 & A 258 & A 258 & 62 & 54.8 & 67 & 95.5 & 76.0 \\
\hline 289 & A 258 & N 258 & 43 & 46.5 & 38 & 97.4 & 70.4 \\
\hline 291 & A 258 & A 258 & 44 & 65.9 & 66 & 93.9 & 82.7 \\
\hline 292 & A 258 & A $25 \mathrm{~s}$ & 16 & 37.5 & 27 & 92.6 & 72.1 \\
\hline 294 & N 241 & N 241 & 16 & 0.0 & 19 & 0.0 & 0.0 \\
\hline 297 & $\mathrm{~N} 246$ & $\mathrm{~N} 241$ & 34 & 2.9 & 57 & 10.5 & 7.7 \\
\hline 298 & N 246 & A 259 & 43 & 48.8 & 55 & 76.4 & 64.3 \\
\hline 299 & A 238 & А 259 & 26 & 73.1 & 28 & 96.4 & 85.2 \\
\hline 301 & $\mathrm{~N} 257$ & N 258 & 53 & 32.1 & 51 & 76.5 & 53.8 \\
\hline 302 & $\mathrm{~N} 257$ & A 258 & 56 & 51.8 & 41 & 92.7 & 69.1 \\
\hline 305 & $\mathrm{~N} 241$ & A 233 & 26 & 0.0 & 29 & 3.4 & 1.8 \\
\hline 316 & N 276 & $\mathrm{~N} 225$ & 25 & 0.0 & 40 & 0.0 & 0.0 \\
\hline 317 & N 225 & A 289 & 25 & 16.0 & 25 & 4.0 & 10.0 \\
\hline 318 & A 288 & N 225 & 32 & 6.3 & 48 & 0.0 & 2.5 \\
\hline 319 & A 283 & $\mathrm{~N} 225$ & 30 & 3.3 & 42 & 7.1 & 5.6 \\
\hline 320 & A 284 & $\mathrm{~N} 225$ & 50 & 10.0 & 60 & 20.0 & 15.5 \\
\hline 321 & A 284 & $\mathrm{~N} 225$ & 27 & 7.4 & 39 & 2.6 & 4.5 \\
\hline 322 & A 284 & N 225 & 48 & 6.3 & 53 & 9.4 & 7.9 \\
\hline 323 & N 297 & N 297 & 29 & 10.3 & 35 & 14.3 & 12.5 \\
\hline 328 & N 284 & A 284 & 28 & 92.9 & 26 & 96.2 & 94.4 \\
\hline 330 & $\mathrm{~N} 284$ & A 284 & 48 & 95.8 & 66 & 90.9 & 93.0 \\
\hline 331 & N 284 & A 284 & 33 & 78.8 & 28 & 82.1 & 80.3 \\
\hline 333 & A 285 & A 285 & 27 & 59.3 & 26 & 84.6 & $\begin{array}{l}71.7 \\
58\end{array}$ \\
\hline $\begin{array}{l}338 \\
339\end{array}$ & A 285 & $\begin{array}{l}\text { A } 285 \\
\text { A } 285\end{array}$ & $\begin{array}{l}26 \\
34\end{array}$ & $\begin{array}{l}53.8 \\
91.2\end{array}$ & $\begin{array}{l}29 \\
45\end{array}$ & $\begin{array}{l}62.1 \\
75.6\end{array}$ & $\begin{array}{l}58.2 \\
82.3\end{array}$ \\
\hline $\begin{array}{l}339 \\
341\end{array}$ & $\begin{array}{l}\text { N } 285 \\
\text { N } 288\end{array}$ & $\begin{array}{l}\text { A } 285 \\
\text { A } 288\end{array}$ & $\begin{array}{l}34 \\
20\end{array}$ & $\begin{array}{l}91.2 \\
90.0\end{array}$ & 25 & 92.0 & 91.1 \\
\hline $\begin{array}{l}541 \\
342\end{array}$ & $\begin{array}{l}\text { N } 288 \\
\text { N } 294\end{array}$ & A 284 & 38 & 31.6 & 52 & 34.6 & 33.3 \\
\hline 343 & N 297 & A 284 & 35 & 25.7 & 47 & 44.7 & 36.6 \\
\hline 344 & $\mathrm{~N} 273$ & A 284 & 42 & 14.3 & 63 & 39.7 & 29.5 \\
\hline 345 & $\mathrm{~N} 273$ & $\begin{array}{l}\text { A } 288 \\
N 320\end{array}$ & 58 & 37.9 & 41 & 48.8 & 42.4 \\
\hline 347 & N 320 & N320 & 32 & 28.1 & 55 & 23.6 & 25.3 \\
\hline
\end{tabular}


TABLE 36.-Percentage of abnormal offspring of 200 families-Continued.

\begin{tabular}{|c|c|c|c|c|c|c|c|}
\hline \multirow{3}{*}{$\begin{array}{l}\text { Mating } \\
\text { No, }\end{array}$} & \multirow{2}{*}{\multicolumn{2}{|c|}{ Parents. }} & \multicolumn{5}{|c|}{ Offspring. } \\
\hline & & & \multicolumn{2}{|c|}{ Male. } & \multicolumn{2}{|c|}{ Female. } & \multirow{2}{*}{$\begin{array}{c}\text { Total } \\
\text { p. ct. } \\
\text { abnormal. }\end{array}$} \\
\hline & Father. & Mother. & $\begin{array}{l}\text { No. } \\
\text { recorded. }\end{array}$ & $\begin{array}{c}\text { P.ct. } \\
\text { abnormal. }\end{array}$ & $\begin{array}{l}\text { No. } \\
\text { recorded. }\end{array}$ & $\begin{array}{c}\text { P. ct. } \\
\text { abnormal. }\end{array}$ & \\
\hline 348 & N 320 & N 320 & 31 & 19.4 & 37 & 21.6 & 20.6 \\
\hline 349 & A 320 & $\mathrm{~N} 320$ & 57 & 36.8 & 65 & 38.5 & 37.7 \\
\hline 350 & $\mathrm{~N} 320$ & N 320 & 37 & 13.5 & 49 & 28.6 & 22.1 \\
\hline 351 & N 320 & A 320 & 36 & 19.4 & 32 & 31.3 & 25.0 \\
\hline 353 & N 320 & N 320 & 37 & 10.8 & 24 & 16.7 & 13.1 \\
\hline 354 & A 284 & N 320 & 37 & 45.9 & 41 & 63.4 & 55.1 \\
\hline 355 & A 284 & $\mathrm{~N} 321$ & 44 & 2.3 & 51 & 21.6 & 12.6 \\
\hline 356 & A 284 & N 322 & 38 & 28.9 & 30 & 60.0 & 42.6 \\
\hline 357 & N 318 & N 318 & 32 & 3.1 & 35 & 11.4 & 7.5 \\
\hline 358 & A 318 & N 322 & 28 & 0.0 & 48 & 2.1 & 1.3 \\
\hline 359 & A 318 & $\mathrm{~N} 322$ & 43 & 2.3 & 33 & 9.1 & 5.3 \\
\hline 364 & N 317 & N 317 & 24 & 0.0 & 24 & 0.0 & 0.0 \\
\hline 365 & N 345 & A 345 & 44 & 36.4 & 52 & 67.3 & 53.1 \\
\hline 366 & $\mathrm{~N} 342$ & A 342 & 39 & 30.8 & 50 & 42.0 & 37.1 \\
\hline 367 & N 330 & A 330 & 42 & 64.3 & 80 & 91.3 & 81.9 \\
\hline 368 & $\mathrm{~N} 330$ & A 330 & 43 & 48.8 & 55 & 87.3 & 70.4 \\
\hline 369 & N 339 & A 339 & 32 & 34.4 & 42 & 76.2 & 58.1 \\
\hline 372 & N 338 & A 338 & 36 & 58.3 & 37 & 89.2 & 74.0 \\
\hline 375 & N 344 & A 344 & 29 & 24.1 & 36 & 52.8 & 40.0 \\
\hline 377 & N 344 & A 330 & 23 & 60.9 & 30 & 93.3 & 79.2 \\
\hline 379 & A 349 & N 349 & 68 & 70.6 & 58 & 70.7 & 70.6 \\
\hline 380 & A 349 & N 349 & 26 & 15.4 & 29 & 24.1 & 20.0 \\
\hline 383 & A 349 & N 349 & 35 & 25.7 & 37 & 59.5 & 43.1 \\
\hline 384 & A 349 & N 349 & 27 & 63.0 & 34 & 88.2 & 77.0 \\
\hline 387 & N 368 & A 368 & 32 & 84.4 & 36 & 83.3 & 83.8 \\
\hline 388 & A 349 & N 349 & 23 & 4.3 & 25 & 12.0 & 8.3 \\
\hline 399 & N 367 & A 367 & 20 & 50.0 & 23 & 95.7 & 74.4 \\
\hline 401 & A 367 & A 367 & 52 & 92.3 & 61 & 93.4 & 92.9 \\
\hline 402 & A 367 & A 367 & 103 & 76.7 & 90 & 94.4 & 85.0 \\
\hline 404 & A 367 & A 367 & 66 & 60.6 & 67 & 64.2 & 62.4 \\
\hline 405 & A 367 & A 367 & 9 & 0.0 & 16 & 0.0 & 0.0 \\
\hline 406 & A 367 & A 367 & 56 & 58.9 & 76 & 86.8 & 75.0 \\
\hline 408 & A 367 & A 367 & 13 & 100.0 & 16 & 100.0 & 100.0 \\
\hline 409 & A 367 & A 367 & 51 & 43.1 & 49 & 93.9 & 68.0 \\
\hline 411 & A 367 & A 367 & 23 & 78.3 & 39 & 82.1 & 80.6 \\
\hline 414 & N 405 & N 405 & 56 & 0.0 & 69 & 0.0 & 0.0 \\
\hline 415 & N405 & N 405 & 75 & 0.0 & 74 & 0.0 & 0.0 \\
\hline 417 & N 405 & N 405 & 38 & 0.0 & 73 & 0.0 & 0.0 \\
\hline 418 & A 379 & N 379 & 32 & 71.9 & 33 & 75.8 & 738 \\
\hline 419 & A 379 & N 379 & 35 & 77.1 & 22 & 100.0 & 83.0 \\
\hline 433 & N 399 & A 399 & 24 & 70.8 & 17 & 88.2 & 78.0 \\
\hline 436 & А 379 & N 379 & 20 & 75.0 & 36 & 88.9 & 83.9 \\
\hline 439 & A 408 & A 408 & 54 & 85.2 & 53 & 81.1 & 83.2 \\
\hline 440 & A 408 & A 408 & 25 & 96.0 & 26 & 100.0 & 98.0 \\
\hline 453 & N wild & A 399 & 65 & 1.5 & 83 & 2.4 & 2.0 \\
\hline 454 & $\mathrm{~N}$ wild & A 399 & 49 & 0.0 & 52 & 0.0 & 0.0 \\
\hline 455 & $\mathrm{~N}$ wild & A 399 & 41 & 36.6 & 32 & 34.4 & 35.6 \\
\hline 456 & $\mathrm{~N}$ wild & A 399 & 42 & 4.8 & 59 & 10.2 & 7.9 \\
\hline 459 & A wild & N wild & 49 & 2.0 & 59 & 15.3 & 9.3 \\
\hline 474 & N 414 & N 414 & 18 & 0.0 & 15 & 0.0 & 0.0 \\
\hline 513 & A 439 & A 439 & 13 & 92.3 & 10 & 100.0 & 95.7 \\
\hline 514 & A 440 & A 440 & 44 & 97.7 & 44 & 97.7 & 97.7 \\
\hline 523 & N 474 & $\mathrm{~N} 474$ & 39 & 0.0 & 37 & 0.0 & 0.0 \\
\hline 533 & A 513 & A 513 & 44 & 95.5 & 54 & 100.0 & 98.0 \\
\hline 548 & A 514 & A 514 & 26 & 96.2 & 37 & 100.0 & 98.4 \\
\hline 557 & A 548 & A 548 & 18 & 94.4 & 29 & 100.0 & 97.9 \\
\hline 564 & A 533 & A 533 & 4 & 100.0 & 4 & 100.0 & 100.0 \\
\hline 575 & N 523 & N 523 & 39 & 0.0 & 20 & 0.0 & 0.0 \\
\hline
\end{tabular}


TABLE 36.-Percentage of abnormal offspring of 200 families-Continued.

\begin{tabular}{|c|c|c|c|c|c|c|c|}
\hline \multirow{3}{*}{$\begin{array}{l}\text { Mating } \\
\text { No. }\end{array}$} & \multirow{2}{*}{\multicolumn{2}{|c|}{ Parents. }} & \multicolumn{5}{|c|}{ Otrspring. } \\
\hline & & & \multicolumn{2}{|c|}{ Male. } & \multicolumn{2}{|c|}{ Femule. } & \multirow{2}{*}{$\begin{array}{l}\text { Toinl } \\
\text { p. ct. } \\
\text { ubmormal. }\end{array}$} \\
\hline & Father. & Mother. & $\begin{array}{l}\text { No. } \\
\text { recurded. }\end{array}$ & $\begin{array}{c}\text { P.cit. } \\
\text { abuormat. }\end{array}$ & $\begin{array}{l}\text { No } \\
\text { recurderl. }\end{array}$ & $\begin{array}{l}\text { P.ct. } \\
\text { aburimal. }\end{array}$ & \\
\hline 576 & N 523 & N 523 & 52 & 0.0 & 48 & 0.0 & 0.0 \\
\hline 582 & N 575 & N 575 & 28 & 0.0 & 37 & 0.0 & 0.0 \\
\hline 584 & N 557 & A 557 & 18 & 100.0 & 24 & 100.0 & 100.0 \\
\hline 585 & N 576 & A 557 & 48 & 4.2 & 45 & 24.4 & 14.0 \\
\hline 587 & N 576 & N 576 & 29 & $0 . \overline{0}$ & 21 & 4.8 & 2.0 \\
\hline 588 & N 576 & N 576 & 55 & 0.0 & 46 & 0.0 & 0.0 \\
\hline 589 & A 564 & A 564 & 24 & 100.0 & 20 & 100.0 & 100.0 \\
\hline 590 & N 588 & N 582 & 48 & 0.0 & 55 & 0.0 & 0.0 \\
\hline 591 & N 588 & N 588 & 1 & 0.0 & 3 & 0.0 & 0.0 \\
\hline 592 & N 587 & N 582 & 32 & 0.0 & 33 & 0.0 & 0.0 \\
\hline 593 & N 587 & N 582 & 39 & 0.0 & 36 & 0.0 & 0.0 \\
\hline 594 & N 585 & N 585 & 73 & 41.1 & 69 & 62.3 & 51.4 \\
\hline 600 & N 588 & N 588 & 55 & 0.0 & 58 & 0.0 & 0.0 \\
\hline 602 & A 589 & A 589 & 21 & 100.0 & 25 & 100.0 & 100.0 \\
\hline 605 & A 584 & A 585 & 30 & 40.0 & 37 & 67.6 & 55.2 \\
\hline 606 & A 584 & A 584 & 2 & 100.0 & 7 & 100.0 & 100.0 \\
\hline 611 & A 585 & $A$ " C $"$ " & $4 \overline{5}$ & 17.8 & 50 & 38.0 & 28.4 \\
\hline 613 & N 592 & N 592 & 38 & 0.0 & 53 & 1.9 & 1.1 \\
\hline 614 & N 593 & $\mathrm{~N} 590$ & 38 & 0.0 & 50 & 2.1 & 1.1 \\
\hline 622 & N 600 & N 591 & 19 & 0.0 & 45 & 4.4 & 3.1 \\
\hline 623 & $\mathrm{~N} 600$ & N 591 & 24 & 0.0 & 35 & 0.0 & 0.0 \\
\hline 626 & A 602 & A 594 & 53 & 32.1 & 60 & 53.3 & 43.4 \\
\hline 632 & A 606 & A 606 & 22 & 100.0 & 19 & 100.0 & 100.0 \\
\hline 633 & A 602 & A 611 & 11 & 90.9 & 14 & 92.9 & 92.0 \\
\hline 639 & A 594 & A 602 & 1 & 100.0 & 7 & 100.0 & 100.0 \\
\hline 641 & A 611 & A 605 & 32 & 87.5 & 49 & 95.9 & 92.6 \\
\hline 642 & A 605 & A 605 & 34 & 55.9 & 43 & 65.1 & 61.0 \\
\hline 643 & A 611 & A 611 & 3 & 100.0 & 4 & 100.0 & 100.0 \\
\hline 657 & N 614 & $\mathrm{~N} 614$ & 31 & 0.0 & 30 & 0.0 & 0.0 \\
\hline 660 & N 622 & N 622 & 44 & 2.3 & 40 & 5.0 & 3.6 \\
\hline 663 & N 623 & N 623 & 42 & 0.0 & 29 & 0.0 & 0.0 \\
\hline 665 & $\mathrm{~N} 613$ & N 622 & 19 & 0.0 & 64 & 0.0 & 0.0 \\
\hline 670 & A 626 & A 602 & 35 & 88.6 & 45 & 100.0 & 95.0 \\
\hline 677 & A 641 & A 626 & 23 & 95.7 & 23 & 100.0 & 97.8 \\
\hline 678 & A 633 & A 633 & 9 & 100.0 & 5 & 100.0 & 100.0 \\
\hline 680 & A 642 & A 642 & 34 & 97.1 & 49 & 100.0 & 98.8 \\
\hline 681 & A 639 & A 639 & 10 & 70.0 & 21 & 100.0 & 90.3 \\
\hline 682 & A 626 & A 626 & 34 & 91.2 & 41 & 100.0 & 96.0 \\
\hline 685 & A 643 & A 633 & 18 & 83.3 & 23 & 100.0 & 92.7 \\
\hline 692 & A 633 & А 633 & 29 & 93.1 & 30 & 96.7 & 94.9 \\
\hline 694 & A 642 & A 632 & 29 & 75.9 & 31 & 83.9 & 80.0 \\
\hline 710 & N 660 & N 657 & 27 & 0.0 & 35 & 0.0 & 0.0 \\
\hline 715 & N 665 & N 663 & 13 & 0.0 & 24 & 0.0 & 0.0 \\
\hline 719 & A 670 & A 677 & 7 & 100.0 & 11 & 100.0 & 100.0 \\
\hline 723 & A 685 & A 682 & 24 & 95.8 & 27 & 100.0 & 98.0 \\
\hline 726 & A 678 & A 680 & 43 & 90.7 & 54 & 100.0 & 95.9 \\
\hline 727 & A 692 & A 692 & 11 & 100.0 & 15 & 100.0 & 100.0 \\
\hline 729 & A 681 & A 682 & . & & 1 & 100.0 & 100.0 \\
\hline 737 & A 694 & A 694 & 9 & 88.9 & 7 & 100.0 & 93.5 \\
\hline 752 & A 726 & A 719 & 45 & 100.0 & 56 & 100.0 & 100.0 \\
\hline 753 & A 726 & A 723 & 27 & 92.6 & 27 & 100.0 & 96.3 \\
\hline 763 & A 727 & A 727 & 12 & 100.0 & 13 & 100.0 & 100.0 \\
\hline 764 & A 726 & A 727 & 29 & 96.6 & 29 & 100.0 & 953 \\
\hline 765 & A 726 & A 729 & 46 & 97.8 & 50 & 100.0 & 99.0 \\
\hline 767 & A 737 & A 737 & 20 & 80.0 & 27 & 100.0 & 91.5 \\
\hline 785 & N 715 & N 715 & 63 & 20.6 & 83 & 20.5 & 20.5 \\
\hline $\begin{array}{l}799 \\
802\end{array}$ & $\begin{array}{l}\text { A } 753 \\
\text { N } 715\end{array}$ & A 753 & 17 & $\begin{array}{r}88.2 \\
0.0\end{array}$ & $\begin{array}{l}38 \\
44\end{array}$ & $\begin{array}{r}92.1 \\
0.0\end{array}$ & $\begin{array}{r}90.9 \\
0.0\end{array}$ \\
\hline 802 & N 715 & N 710 & 40 & 0.0 & 44 & & \\
\hline
\end{tabular}


TABLE 36.-Percentage of abnormal offspring of 200 families-Continued.

\begin{tabular}{|c|c|c|c|c|c|c|c|}
\hline \multirow{3}{*}{$\begin{array}{c}\text { Mating } \\
\text { No. }\end{array}$} & \multirow{2}{*}{\multicolumn{2}{|c|}{ Parents. }} & \multicolumn{5}{|c|}{ Offspring. } \\
\hline & & & \multicolumn{2}{|c|}{ Male. } & \multicolumn{2}{|c|}{ Female. } & \multirow{2}{*}{$\begin{array}{c}\text { Total } \\
\text { p. ct. } \\
\text { abnormal }\end{array}$} \\
\hline & Father. & Mother. & $\begin{array}{l}\text { No. } \\
\text { recorded. }\end{array}$ & $\begin{array}{c}\text { P. et. } \\
\text { abnormal. }\end{array}$ & $\begin{array}{l}\text { No. } \\
\text { recorded. }\end{array}$ & $\begin{array}{c}\text { P. et. } \\
\text { abnormal }\end{array}$ & \\
\hline 804 & N 710 & N715 & 19 & 0.0 & 19 & 5.3 & 2.6 \\
\hline 808 & A 752 & A 765 & 21 & 95.2 & 25 & 100.0 & 97.8 \\
\hline 813 & A 763 & A 763 & 8 & 100.0 & 9 & 100.0 & 100.0 \\
\hline 816 & A 764 & A 764 & 26 & 100.0 & 23 & 100.0 & 100.0 \\
\hline 818 & A 767 & A 767 & 13 & 100.0 & 12 & 100.0 & 100.0 \\
\hline 831 & N 804 & N 802 & 34 & 0.0 & 35 & 0.0 & 0.0 \\
\hline 833 & N 802 & N 802 & 40 & 0.0 & 53 & 1.9 & 1.1 \\
\hline 836 & N 785 & N 785 & 46 & 19.6 & 63 & 38.1 & 30.3 \\
\hline 851 & A 799 & A 799 & 6 & 100.0 & 11 & 100.0 & 100.0 \\
\hline 853 & A 816 & A 808 & 25 & 100.0 & 41 & 100.0 & 100.0 \\
\hline 858 & A 808 & A 808 & 38 & 100.0 & 36 & 100.0 & 100.0 \\
\hline 880 & N 836 & N 831 & 52 & 5.8 & 83 & 7.2 & 6.7 \\
\hline 882 & N 833 & N 836 & $5 \overline{5}$ & 0.0 & 55 & 3.6 & 1.8 \\
\hline 886 & A 851 & A 853 & 29 & 100.0 & 44 & 100.0 & 100.0 \\
\hline 889 & A 858 & A 853 & 16 & 87.5 & 35 & 97.1 & 94.1 \\
\hline 898 & N 857 & N 857 & 55 & 3.6 & 63 & 1.6 & 2.5 \\
\hline 899 & N 857 & N 857 & 50 & 2.0 & 33 & 0.0 & 1.2 \\
\hline 900 & A 857 & N 857 & 38 & 2.6 & 44 & 13.6 & 8.5 \\
\hline 902 & A 886 & A 889 & 28 & 100.0 & 36 & 97.2 & 98.4 \\
\hline 907 & A 886 & A 886 & 37 & 100.0 & 27 & 100.0 & 100.0 \\
\hline 908 & A 886 & A 886 & 42 & 100.0 & 55 & 100.0 & 100.0 \\
\hline $\begin{array}{l}917 \\
926\end{array}$ & A 886 & A 886 & 39 & 100.0 & 39 & 100.0 & 100.0 \\
\hline 926 & N 880 & N 880 & 49 & 6.1 & 50 & 6.0 & 6.1 \\
\hline XXII & A 886 & N 882 & 20 & 65.0 & 27 & 74.1 & 70.2 \\
\hline 943 & A 902 & A 902 & 59 & 98.3 & 74 & 100.0 & 99.2 \\
\hline 946 & A XXII & A XXII & 44 & 40.9 & 62 & 62.9 & 53.8 \\
\hline 947 & A XXII & N XXII & 50 & 52.0 & 78 & 66.7 & 60.9 \\
\hline 948 & N XXII & $\mathrm{N}$ XXII & 54 & 25.9 & 59 & 40.7 & 36.9 \\
\hline 953 & N926 & N 926 & 40 & 0.0 & 58 & 13.8 & 8.2 \\
\hline 954 & N 926 & A 908 & 43 & 32.6 & 46 & 58.7 & 46.1 \\
\hline 955 & N 926 & A 908 & 40 & 27.5 & 53 & 26.4 & $26 . \overline{9}$ \\
\hline 967 & A XXII & A XXII & 37 & 54.1 & 46 & 71.7 & 63.9 \\
\hline 968 & A XXII & A XXII & 23 & 87.0 & 32 & 100.0 & 94.5 \\
\hline 970 & N XXII & $\mathrm{N}$ XXII & 44 & 31.8 & 43 & 34.9 & 33.3 \\
\hline 983 & N 946 & N946 & 46 & 39.1 & 43 & 60.5 & 49.4 \\
\hline 984 & A 946 & A 946 & 33 & 81.8 & 51 & 90.2 & 86.9 \\
\hline 985 & A 946 & N 946 & 41 & 56.1 & 41 & 78.0 & 67.1 \\
\hline $\begin{array}{l}986 \\
989\end{array}$ & N 947 & N 947 & 29 & 24.1 & 36 & 38.9 & 32.3 \\
\hline 989 & A 947 & N 947 & 27 & 66.7 & 29 & 82.8 & 75.0 \\
\hline $\begin{array}{r}997 \\
1006\end{array}$ & A 943 & А 943 & 27 & 77.8 & 28 & 85.7 & 81.8 \\
\hline 1006 & A 930 & N 957 & 18 & 55.5 & 20 & 60.0 & 57.9 \\
\hline 1017 & N 953 & N 953 & 7 & 0.0 & 8 & 12.5 & 7.3 \\
\hline 1021 & A 947 & N 947 & 21 & 47.6 & 22 & 45.5 & 46.5 \\
\hline 1064 & N 997 & A 997 & 30 & 50.0 & 38 & 78.9 & 66.2 \\
\hline 1069 & N 1017 & N 1017 & 24 & 0.0 & 40 & 2.5 & 1.6 \\
\hline 1071 & A 981 & N 1006 & 4 & 0.0 & 7 & 14.3 & 9.1 \\
\hline 1111 & N 1062 & N 1069 & 9 & 0.0 & 9 & 0.0 & 0.0 \\
\hline 1117 & N 1064 & N 1064 & 19 & 26.3 & 18 & 4.4 & 35.1 \\
\hline 1118 & N 1064 & N 1064 & 55 & 23.4 & 63 & 39.7 & 32.2 \\
\hline 1123 & N 1069 & N 1069 & 52 & 0.0 & 65 & 0.0 & 0.0 \\
\hline 1124 & N 1069 & N 1069 & 19 & 0.0 & 36 & 0.0 & 0.0 \\
\hline $\begin{array}{l}1141 \\
1153\end{array}$ & 2 A 1102 & 3 N 1071 & 39 & 10.3 & 58 & 8.6 & 9.3 \\
\hline $\begin{array}{l}1153 \\
1154\end{array}$ & N 1111 & N 1111 & 69 & 0.0 & 74 & 2.7 & 1.4 \\
\hline $\begin{array}{l}1134 \\
1156\end{array}$ & N 1111 & N 1111 & 51 & 2.0 & 47 & 6.4 & 4.1 \\
\hline 1158 & N 1111 & N 1111 & 39 & 51 & 53 & 5.7 & 5.4 \\
\hline 1166 & N 1158 & N 1118 & 2 & 0.0 & 6 & 16.7 & 12.5 \\
\hline 1172 & N 1156 & $\begin{array}{l}\text { N } 1158 \\
\text { N } 1156\end{array}$ & 42 & 11.9 & 58 & 20.7 & 17.0 \\
\hline 1176 & N 1154 & N 1156 & $\begin{array}{l}37 \\
70\end{array}$ & 8.1 & 42 & 21.4 & 15.2 \\
\hline 1177 & N 1154 & N 1156 & 53 & $\begin{array}{l}2.9 \\
7.5\end{array}$ & $\begin{array}{l}69 \\
59\end{array}$ & 1.4 & 2.2 \\
\hline & & & & 7.5 & 59 & 13.6 & 10.7 \\
\hline
\end{tabular}


TABLE 36. -Percentage of abnormal offspring of 200 families-Continued.

\begin{tabular}{|c|c|c|c|c|c|c|c|}
\hline \multirow{3}{*}{$\begin{array}{l}\text { Mating } \\
\text { No. }\end{array}$} & \multirow{2}{*}{\multicolumn{2}{|c|}{ Parents. }} & \multicolumn{5}{|c|}{ Olfopring. } \\
\hline & & & \multicolumn{2}{|c|}{ Male. } & \multicolumn{2}{|c|}{ Fomale. } & \multirow{2}{*}{$\begin{array}{c}\text { Total } \\
\text { pect. } \\
\text { abnirmal. }\end{array}$} \\
\hline & Father. & Mother. & $\begin{array}{l}\text { No. } \\
\text { recorded. }\end{array}$ & $\begin{array}{c}\text { l'.et. } \\
\text { abuormal. }\end{array}$ & $\begin{array}{l}\text { Nuy } \\
\text { recorded. }\end{array}$ & $\begin{array}{l}\text { P.ct. } \\
\text { abnormat. }\end{array}$ & \\
\hline 1181 & A 1141 & 4 N 1141 & 39 & 10.3 & 70 & 22.9 & 18.3 \\
\hline 1190 & 2 A 1141 & 4 N 1141 & 45 & 11.1 & 53 & 11.3 & 11.2 \\
\hline 1192 & N 1177 & N 1177 & 39 & 2.6 & 28 & 17.9 & 9.0 \\
\hline 1193 & N 1177 & N 1177 & 49 & 2.0 & 73 & 1.3 & 1.6 \\
\hline 1197 & N 1176 & N 1176 & 61 & 0.0 & 53 & 1.9 & 0.9 \\
\hline 1204 & N 1166 & N 1166 & 2 & 0.0 & 6 & 0.0 & 0.0 \\
\hline 1208 & A 1181 & $3 \mathrm{~N} 1181$ & 49 & 8.2 & 53 & 11.3 & 9.8 \\
\hline 1213 & N 1166 & N 1166 & 33 & 3.0 & 47 & 23.4 & 15.0 \\
\hline 1217 & 3 A 1190 & $4 N 1190$ & 28 & 21.4 & 29 & 41.4 & 31.6 \\
\hline 1221 & N 1197 & N 1197 & 43 & 4.7 & 47 & 6.4 & $5 t$ \\
\hline 1226 & N 1193 & N 1193 & 29 & 0.0 & 21 & 9.5 & 4.0 \\
\hline 1229 & N 1204 & N 1204 & 5 & 0.0 & 11 & 0.0 & 0.0 \\
\hline 1254 & N 1229 & N 1229 & 23 & 0.0 & 21 & 0.0 & 0.0 \\
\hline 1256 & N 1226 & N 1226 & 39 & 2.6 & 46 & 10.9 & 7.1 \\
\hline 1266 & N 1254 & N 1254 & 25 & 4.0 & 26 & 3.8 & 3.9 \\
\hline 1268 & N 1254 & N 1254 & 13 & 0.0 & 12 & 0.0 & 0.0 \\
\hline 1269 & N 1254 & N 1254 & 4 & 0.0 & 9 & 0.0 & 0.0 \\
\hline 1282 & N 1256 & N 1256 & 4 & 0.0 & 4 & 0.0 & 0.0 \\
\hline 1286 & N 1269 & N 1269 & 27 & 0.0 & 29 & 0.0 & 0.0 \\
\hline 1293 & N 1286 & N 1286 & 55 & 1.8 & 53 & 5.7 & 3.7 \\
\hline 1300 & N 1282 & N $128^{\circ}$ & 20 & 0.0 & 24 & 0.0 & 0.0 \\
\hline 1309 & N 1293 & N 1293 & 12 & 0.0 & 14 & 0.0 & 0.0 \\
\hline 1327 & N 1300 & N 1300 & 52 & 0.0 & 48 & 0.0 & 00 \\
\hline 1347 & N 1327 & N 1327 & 46 & 0.0 & 59 & 0.0 & 0.0 \\
\hline 1394 & N 1347 & N 1347 & 61 & 0.0 & 73 & 0.0 & 0.0 \\
\hline 1428 & $3 N 1394$ & $3 \mathrm{~N} 1394$ & 62 & 1.6 & 66 & 0.0 & 0.8 \\
\hline 1454 & N 1428 & N1428 & 65 & 0.0 & 64 & 0.0 & 0.0 \\
\hline 1476 & N 1454 & N 1454 & 43 & 0.0 & 46 & 0.0 & 0.0 \\
\hline 1533 & N 1476 & N 1476 & 34 & 0.0 & 33 & 0.0 & 0.0 \\
\hline 1565 & N 1533 & N 1533 & 64 & 0.0 & 74 & 0.0 & 0.0 \\
\hline 1587 & * A 1498 & * A 1498 & 37 & 24.3 & 40 & 15.0 & 19.5 \\
\hline 1588 & * A 1492 & * A 1492 & 44 & 2.3 & 44 & 0.0 & 1.1 \\
\hline 1626 & N 1565 & N 1565 & 25 & 0.0 & 32 & 0.0 & 0.0 \\
\hline 1668 & A 1587 & A 1588 & 43 & 2.3 & 69 & 2.9 & 2.7 \\
\hline 1687 & A 1587 & N 1587 & 55 & 1.8 & 63 & $12 . .7$ & 7.6 \\
\hline 1701 & N 1626 & N 1626 & 77 & 0.0 & 68 & 0.0 & 0.0 \\
\hline 1722 & N 1668 & N 1668 & 30 & 0.0 & 70 & 4.3 & 3.0 \\
\hline 1785 & N 1687 & A 1687 & 29 & 10.3 & 33 & $15 \cdot 2$ & 12.9 \\
\hline 1787 & N 1701 & N1701 & 32 & 0.0 & 40 & 0.0 &.$n$ \\
\hline 1788 & A 1668 & N 1668 & 5 & 0.0 & 80 & 11.3 & 10.6 \\
\hline 1830 & N 1787 & N 1787 & 45 & 0.0 & 88 & 0.0 & 0.0 \\
\hline 1857 & N 1722 & N 1722 & 20 & 10.0 & 62 & 6.4 & 7.3 \\
\hline 1859 & A 1785 & N 1785 & 21 & 0.0 & 30 & 33.3 & 19.6 \\
\hline 1890 & N 1830 & N 1830 & 7 & 0.0 & 8 & 0.0 & 0.0 \\
\hline 1961 & N 1859 & A 1859 & 49 & 16.3 & 44 & 9.1 & 12.9 \\
\hline 2006 & N 1788 & A 1788 & 18 & 5.6 & 40 & 25.0 & $19 . n$ \\
\hline 2013 & N 1890 & N 1890 & 12 & 0.0 & 16 & 0.0 & 0.0 \\
\hline 2084 & A 1857 & A 1857 & 8 & 12.5 & 23 & 8.7 & $9 . \overline{7}$ \\
\hline 2194 & N 2013 & N 2013 & 18 & 0.0 & 9 & 0.0 & 0.0 \\
\hline 2224 & A 1961 & A 2006 & 13 & 15.4 & 28 & 39.3 & 31.7 \\
\hline 2226 & A 1961 & A 2006 & 68 & 10.3 & 99 & 33.3 & 24.0 \\
\hline 2296 & A 2084 & A 21084 & 25 & 28.0 & 10 & 30.0 & 28.6 \\
\hline 2313 & $\mathrm{~N} 2194$ & N $219 t$ & 14 & 0.0 & 23 & 0.0 & 0.0 \\
\hline 2366 & А 2296 & A 2224 & 8 & 50.0 & 16 & 43.8 & 45.8 \\
\hline 2367 & $\mathrm{~N} 2313$ & N 2313 & 11 & 0.0 & 15 & 0.0 & 0.0 \\
\hline 2458 & $\mathrm{~N} 2367$ & N2367 & 24 & 0.0 & 21 & 0.0 & ก. ก \\
\hline 2471 & A 2366 & A 2366 & 78 & 79.5 & 11.1 & 90.3 & 8.9 .9 \\
\hline 2503 & N 2458 & N $245 S$ & 53 & 0.0 & 46 & 0.0 & $\begin{array}{r}0.0 \\
1000\end{array}$ \\
\hline 2524 & A 2471 & A 2471 & 45 & 100.0 & 61 & 100.0 & 100.0 \\
\hline
\end{tabular}

-From wild material (see page 13). 


\section{THE EFFECT OF SEXUAL SELECTION.*}

It is relatively easy to get by artificial selection a strain of Drosophila ampelophila in which practically all the individuals possess extra wingveins. Also, by selection one can reduce the amount of venation. The latter strain is manifestly not fitted to maintain itself, because the wings, deprived of the support of the veins, droop and catch in the food of the insect, resulting in the insect's death. On the other hand, the wings of the extra-veined race are strong, the individuals are vigorous and fertile. What would be the fate of such a race if turned loose in nature (a) where they would find plain-winged individuals with which to breed and $(b)$ where they were isolated from plain-winged individuals? Reasoning from the fate of most feral domestic races, one would expect that in the former case they would soon disappear, although the reason assigned for their disappearance would be the vague one that they would be "swamped." In the latter case many would expect them to keep the domestic characteristics.

Two cubic feet of space and a few decaying bananas form conditions sufficiently feral for the purpose of testing what would happen. On May 2 I released in a large battery-jar an equal number of flies from one of my extra-veined strains and from one of my plain-winged strains. This would clearly give the extra-veined an advantage, for not often will a new form make up 50 per cent of the population. On May 19 only 26 per cent of the flies in the jar showed extra veins and these veins were not as pronounced as those of the original 50 per cent. By May 26 the number was reduced to 11 per cent. It was 7 per cent on June 9, and two weeks later (June 23) only 1 per cent showed any trace of extra veins.

On February 19 I released in a similar jar a population of flies selected from an extra-veined race on the basis of well-developed extra veins. No plain-winged flies were introduced. However, after six weeks (March 31) only 93 per cent showed extra veins and in none of these cases were the extra veins very strong. On April 24 there were only 84 per cent; May 20, 72 per cent; June 23, 49 per cent; and by August 3 only 5 per cent showed any trace of extra veins.

As has been shown, plain-winged individuals occasionally turn up in carefully-bred extra-veined races, but it was, at first, puzzling to see how these occasional "reversions" could get such a foothold as to supplant the extra-veined flies which were in the jar by the hundreds. The explanation was found while testing the selective value of the prominent male secondary sexual character on the anterior tibiæ-the large tibial comb.

*Paper read before the American Society of Naturalists, Boston meeting, 1909. 
I cut them off of a plain-winged male and left them on a male of the extra-veined race and vice versa. These two males were then given to a female as mates. By a study of her offspring I could tell, in a rough way, which mate she preferred. To my surprise she chose almost exclusively the normal male, whether he had tibial adornments or not.

Then, without removing the tibial combs, I gave plain-winged and extra-veined individuals the choice between mates which, as far as I could determine, were alike in all particulars such as age, nutrition, activity, and time since last copulation, but differed in that one had extra veins while the other had not. I watched each experiment until copulation had taken place. When the extra venation in one mate was great, the chooser, whether male or female, normal or extra-veined, chose the normal mate. I then tried weaker degrees of the character and in 85 experiments, mostly with flies having the extra veins only very slightly developed, 61 of the choices were in favor of the wild type.

The basis upon which these flies discriminate against extra-veined individuals when choosing a mate is a matter for further study. There is an elaborate "courtship," in which the flirting of the wings in front of the prospective mate plays a large part. It seems as though a choice were made on the basis of sight, but I doubt whether that is the case. However, there is no doubt of the choice. It is a clear case of the undoing of artificial selection by sexual selection. 


\section{DISUSE AND DEGENERATION.*}

One of the several much-discussed but little-tested problems of the theory of evolution is that of the inherited effects of disuse. I believe that there is a pretty general idea that when a species no longer has need for an organ that organ will degenerate. The explanations of this degeneration are varied, but the most popular seem to be the inheritance of acquired characters, panmixia and selection. It is indisputable that in the life of an individual many unused organs do degenerate, but it is far from proven or even satisfactorily indicated that this ontogenetic degeneration is followed by a phylogenetic degeneration. There is no doubt that many degenerate organs are not used in any way; but who can say whether this disuse has preceded degeneration as a cause or merely followed as a necessary consequence? Before attempting to explain the phylogenetic degeneration which follows disuse it seems desirable to find a clear case of such a sequence, and this quest was the purpose of the experiment with Drosophila ampelophila upon which I wish briefly to report.

These insects are normally very good fliers, possessing wings which are relatively quite large. In my experiments, however, they were confined in glass vials barely large enough to contain the food. The only opportunity they had to fly was when they were transferred from one vial to another. This was done only three times a week. Such flight could at most not be more than $5 \mathrm{~cm}$., and was, as a matter of fact, rarely made, as they usually walked.

The experiments are complicated by several facts which must be considered. These fall into two groups:

First, those which might explain the absence of degeneration in the wings. Disuse does not affect, during the life of an individual, the wing-dimensions, for after an insect's wings are expanded there is no change in them and, of course, they are not subject to the effects of use and disuse before they are expanded. However, the degeneration of beetle-wings when the elytra are fused, of the wings of cave insects, of parasites, and of the wings of many female Lepidoptera are used as stock examples of disuse. Furthermore, if there be anything in the theory of hormones (of which Cunningham has recently made so much) or the various forms of the memory theory of inheritance, we would expect phylogenetic degeneration because of the germ-plasm receiving the news that the wing:s are not being used, providing the plasm is in condition to

*Paper read before the American Society of Zoologists, Baltimore meeting, 1908. 
receive and act upon such a stimulus. In certain insects the germ-cells are all practically matured before or by the time the wings are expanded and ready for use. This, however, is not the case with Drosophila. Not only are the germ-eells not all matured by the time it becomes adult, but they are in all stages of development and continue to mature, a few at a time, for a month thereafter. In these experiments I rarely used as parents the individuals coming from first-laid eggs, so that there were strong chances of my using affected germ-plasm if such exists. Any experiment, such as this, is always open to the criticism that it has not been sufficiently long continued, but I am sure that most will agree that 43 generations, combined with micloscopic measurements and the delicacy of biometric analysis, ought to give a satisfactory indication of what is taking place.

The second set of considerations might explain any observed degenerations without reference to the disuse. Excessive inbreeding was practiced, sister usually being bred to brother. This was necessary for. if I had planned to stop at this point and had wished to entirely avoid inbreeding, I would have needed more than 8 trillion flies with which to start the work. Inbreeding is supposed to lead to degeneration and might thus be solely accountable for degeneration, or it might assist disuse. Unnatural conditions might have adversely affected the flies. Confinement itself, apart from the entailed disuse, might at least help to bring about degeneration. Furthermore, I kept the insects breeding winter and summer, with no rest for hibernation and with no change of food. There was no conscious selection favoring perfect and large wings, as all measurements of this strain were made quite recently and the variations in wing-dimensions are not readily appreciable, hence the removal of selection in favor of good wings might result in panmixia and consequent degeneration. Finally, I was constantly on the lookout for signs of degeneration, as I hoped and still do hope to produce a wingless Drosophila. My desire might have influenced my actions and an unconscious selection on my part might have reduced the size of the wings without disuse playing a part.

The only necessary answer to this second set of considerations is that, in spite of the possibility of the degenerating effect of disuse being helped by inbreeding, unnatural conditions, panmixia, or selection, there has been no degeneration.

Evidence of degeneration was sought for by carefully measuring the expanded wings of the individuals belonging to successive stages of the experiment. In making these measurements one may not mix the sexes because of the sexual difference in size. Therefore the females alone were used, since among insects it is more commonly the females which have degenerate wings. The results are shown in table 37 , where 33 units of length equal $1 \mathrm{~mm}$. 
TABLE 37.-Mean wing-dimensions at various periods of continued disuse.

\begin{tabular}{|r|r|r|r|}
\hline Generations of disuse. & Length of wing. & Breadth of wing. & Length $\times$ breadth. \\
\hline 1st to 3rd............... & $67.00 \pm 0.12$ & $32.55 \pm 0.07$ & $2223.12 \pm 8.85$ \\
17th to 19th .......... & $66.50 \pm 0.11$ & $33.60 \pm 0.06$ & $2281.12 \pm 7.41$ \\
33rd to 35th ........... & $64.91 \pm 0.12$ & $31.98 \pm 0.06$ & $2115.44 \pm 7.42$ \\
41st to 43rd.......... & $67.67 \pm 0.18$ & $34.06 \pm 0.08$ & $2358.94 \pm 11.46$ \\
\hline
\end{tabular}

If the experiment had stopped at the end of the thirty-fifth generation it would have appeared from this table that the wings were actually getting smaller, since the area, as judged by length $\times$ breadth, was smaller in the second lot than in the first, and still smaller in the thirdthe difference being nearly ten times the expected error. However, this would have been a hasty conclusion. The fourth lot is as much larger than the first as the third is smaller. So we must conclude that there is no evidence that the constant disuse of the wings during more than 40 generations has had any effect.

\section{BIBLIOGRAPHY.}

BLANCHARD, N.

1903. On the inheritance in thoroughbred horses. Biometrika, II, 229-234. Castle, W. E.

1905. Heredity of coat characters in guinea-pigs and rabbits. Carnegie Institution of Washington, Publication No. 23.

$1906 a$. The origin of a polydactylous race of guinea-pigs. Carnegie Institution of Washington, Publication No. 49.

1906b. Inbreeding, cross-breeding, and sterility in Drosophila. Science, n. s., CúnOT, L. xxiII, No. 578. (See also Proc. Am. Acad., XLI, No. 33.)

1904. L'hérédite de la pigmentation chez les souris. ( $3^{\text {me }}$ note.) Arch. Zool. Exper. et Gén., sér. 4, tom. 2, Notes et Revue, pp. xlv-lvi.

DAVENPORT, C. B.

1910. The imperfection of dominance and some of its consequences. Amer. Nat. XLIV, No. 519.

JENNINGS, H. S.

1908. Heredity, variation, and evolution in Protozoa. II. Proc. Am. Phil. Soc., XLVII, No. 190, p. 523.

LARRABEe, A. P.

1906. The optic chiasma of Teleosts: A study of inheritance. Proc. Am. Acad.

LuTz, F. E. XLII, No. 12.

1903. Note on the influence of change in sex on the intensity of heredity. Biometrika, II, pp. 237-240.

1907. Paper read at the Seventh International Zoological Congress. 1908. Combinations of alternative and blending inheritance. Science, n. s.,
XXVIII, No. 714.

PEARSON, KARL.

1900. On the inheritance of characters not capable of exact quantitative measurement. Phil. Trans., A., CXCV, pp. 115-117.

Prizbram, Hans.

1907. Vererbungsversuche uber asymmetrische Augenfarbung bein Angorakatzen. Archiv f. Entwicklungsmechanik, XXV, 260-265. 



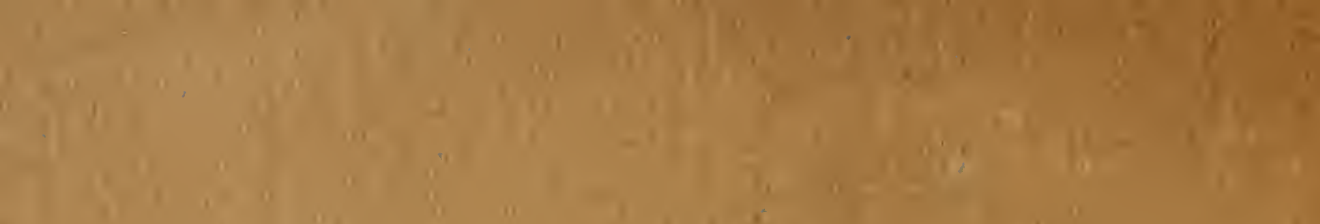

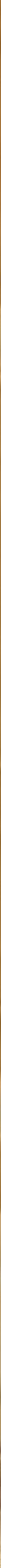




Girylord

PAMPHLET BINDER

Syracuse, N. Y.

Slackion, Colif. 


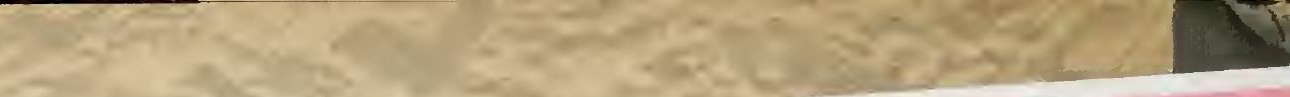

North Carolina State University Libraries

QH371 L8

QTPE LENTS WITH DROSOPHILA AMPELOPHILA CONCE

EXPERIMENTS WITH DROSO H I I H H I I II I

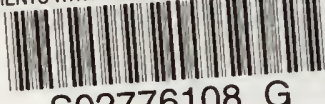

S02776108 G 